\title{
Intraspinal Grafting of Serotonergic Neurons Modifies Expression of Genes Important for Functional Recovery in Paraplegic Rats
}

\author{
Krzysztof Miazga $\mathbb{D D}^{1}{ }^{1}$ Hanna Fabczak, ${ }^{1}$ Ewa Joachimiak, ${ }^{1}$ Małgorzata Zawadzka, \\ Lucja Krzemień-Ojak, ${ }^{1}$ Marek Bekisz ${ }^{(D)}{ }^{1}$ Anna Bejrowska, ${ }^{1}$ Larry M. Jordan, \\ and Urszula Sławińska ${ }^{1}{ }^{1}$ \\ ${ }^{1}$ Nencki Institute of Experimental Biology, Polish Academy of Sciences, Warsaw, Poland \\ ${ }^{2}$ Department of Physiology and Phatophysiology, University of Manitoba, Winnipeg, MB, Canada
}

Correspondence should be addressed to Urszula Sławińska; u.slawinska@nencki.gov.pl

Received 18 February 2018; Revised 23 May 2018; Accepted 4 June 2018; Published 25 July 2018

Academic Editor: Junichi Ushiba

Copyright (c) 2018 Krzysztof Miazga et al. This is an open access article distributed under the Creative Commons Attribution License, which permits unrestricted use, distribution, and reproduction in any medium, provided the original work is properly cited.

\begin{abstract}
Serotonin (5-hydroxytryptamine; 5-HT) plays an important role in control of locomotion, partly through direct effects on motoneurons. Spinal cord complete transection (SCI) results in changes in 5-HT receptors on motoneurons that influence functional recovery. Activation of $5-\mathrm{HT}_{2 \mathrm{~A}}$ and $5-\mathrm{HT}_{7}$ receptors improves locomotor hindlimb movements in paraplegic rats. Here, we analyzed the mRNA of $5-\mathrm{HT}_{2 \mathrm{~A}}$ and $5-\mathrm{HT}_{7}$ receptors (encoded by Htr2a and Htr7 genes, resp.) in motoneurons innervating tibialis anterior (TA) and gastrocnemius lateralis (GM) hindlimb muscles and the tail extensor caudae medialis (ECM) muscle in intact as well as spinal rats. Moreover, the effect of intraspinal grafting of serotonergic neurons on Htr2a and Htr7 gene expression was examined to test the possibility that the graft origin 5-HT innervation in the spinal cord of paraplegic rats could reverse changes in gene expression induced by SCI. Our results indicate that SCI at the thoracic level leads to changes in Htr2a and Htr7 gene expression, whereas transplantation of embryonic serotonergic neurons modifies these changes in motoneurons innervating hindlimb muscles but not those innervating tail muscles. This suggests that the upregulation of genes critical for locomotor recovery, resulting in limb motoneuron plasticity, might account for the improved locomotion in grafted animals.
\end{abstract}

\section{Introduction}

Motoneurons (MNs) respond to 5-HT with an increase in excitability [1-3]. We and others have previously argued that $5-\mathrm{HT}_{2 \mathrm{~A}}$ and $5-\mathrm{HT}_{7}$ receptors are important in the initiation and control of locomotion [3-12], and that these receptors mediate hindlimb locomotor recovery produced in paraplegic animals after replacement of 5-HT neurons into the sublesional spinal cord by grafts of fetal brainstem [10, 13]. One of the effects of spinal cord transection, which interrupts the 5-HT pathway from the brainstem to the spinal cord, is plasticity in 5-HT receptors of spinal MNs $[14,15]$. The $5-\mathrm{HT}_{7}$ receptors have been implicated in control of $\mathrm{MNs}$ or reflexes involved in respiration, jaw movement, micturition, and locomotion [16-21] as well as in the control of pain after spinal cord injury $[22,23]$, while the $5-\mathrm{HT}_{2 \mathrm{~A}}$ receptor has been implicated in the control of respiration, development of spasticity in tail and hindlimb digit MNs, and the recovery of locomotor capability after spinal cord injury [24-27]. Intraspinal grafting of serotonergic neurons leads to functional recovery and involves activation of $5-\mathrm{HT}_{2 \mathrm{~A}}$ and 5$\mathrm{HT}_{7}$ receptors [10]. We asked whether the facilitation of locomotion by our grafts might be mediated by plasticity in these key receptors that are necessary for locomotor recovery.

The $5-\mathrm{HT}_{7}$ receptor protein is found in MNs of the spinal cord [28], with some MN populations (e.g., Onuf s nucleus) more intensely labeled than others. MNs in the L4 spinal cord, where MNs to hindlimb muscles are located, displayed 
a relatively low level of labeling. These receptors have been shown to have excitatory effects on some MNs, including phrenic MNs [29] and trigeminal MNs [19], but not hypoglossal respiratory $\mathrm{MNs}[30,31]$.

The afterhyperpolarization (AHP) in many types of neurons is reduced by $5-\mathrm{HT}$, and this effect may be mediated by $5-\mathrm{HT}_{7}$ receptors $[19,32]$. MNs of limb muscles have reduced AHPs during locomotion $[33,34]$, and lamprey MNs have reduced AHP due to 5 -HT $[35,36]$. This effect serves as a means of increasing $\mathrm{MN}$ spiking.

The $5-\mathrm{HT}_{2 \mathrm{~A}}$ receptor is abundant in ventral horn MNs $[37,38]$, with variable expression levels depending upon the functional role of the cell. For example, $5-\mathrm{HT}_{2 \mathrm{~A}}$ receptors are differentially distributed on $\mathrm{MNs}$ to the physiological extensor soleus muscle and extensor digitorum longus, a physiological flexor muscle [39]. Plasticity in the $5-\mathrm{HT}_{2 \mathrm{~A}}$ receptor protein has been examined after sacral spinal cord injury, where the changes have been suggested to underlie the development of tail spasticity (reviewed in $[14,15]$ ). Contusive spinal cord injury at the thoracic level resulted in upregulation of $5-\mathrm{HT}_{2 \mathrm{~A}}$ receptor protein in $\mathrm{MNs}$ of the rostral dorsolateral nucleus innervating the plantar muscles of the foot, with an associated increase in the H-reflex recorded from the plantar muscles of the hindpaw [40]. Cervical spinal cord hemisections give rise to increased $5-\mathrm{HT}_{2 \mathrm{~A}}$ receptor protein in phrenic $\mathrm{MNs}$ and their subsequent increased excitability [27].

Chopek et al. [41] demonstrated that the extensor monosynaptic reflex in hindlimb MNs of passively cycled spinal rats responded to quipazine (a $5-\mathrm{HT}_{2}$ agonist). This plasticity could be related to changes in 5-HT receptors in MNs; 5$\mathrm{HT}_{2 \mathrm{~A}}$ receptor mRNA increased after injury and increased further after passive cycling [42]. An increase in $5-\mathrm{HT}_{2 \mathrm{~A}}$ mRNA after sacral SCI was observed in tail MNs [43]. Chopek et al. [42] found no change in $5-\mathrm{HT}_{7}$ receptor gene expression in lumbar MNs 3 months after spinal cord transection, but passive cycling increased $5-\mathrm{HT}_{7}$ receptor mRNA. Giroux et al. [44] found spinal 5-HT receptors increased at 15 and 30 days after spinal cord injury, but returned to baseline levels after 60 days or more. They used $[3 \mathrm{H}] 8-\mathrm{OH}-\mathrm{DPAT}$ to label $5-\mathrm{HT}$ receptors, a ligand that can bind to $5-\mathrm{HT}_{7}$ receptors.

There is increasing evidence that activation of specific serotonin receptors in the spinal cord is effective for enhancing locomotor recovery in spinal rats $[11,45,46]$. Out of many serotonergic receptors present in the spinal cord, the $5-\mathrm{HT}_{2 \mathrm{~A}}$ and $5-\mathrm{HT}_{7}$ receptors are the major ones implicated in the control of locomotion [3, 6, 7, 12, 25, 47-49]. The most commonly used agonists that are effective in enhancing the locomotor hindlimb movements when applied systemically are quipazine, which has high affinity for both $5-\mathrm{HT}_{2 \mathrm{~A}}$ and $5-\mathrm{HT}_{2 \mathrm{C}}$ receptors and 8-hydroxy-2-(di-n-propylamino)-tetralin (8-OH-DPAT), which binds selectively to $5-\mathrm{HT}_{7}$ and $5-\mathrm{HT}_{1 \mathrm{~A}}$ receptors $[46,47,50]$. We previously demonstrated that intraspinal grafting of embryonic brainstem tissue containing serotonergic neurons below a thoracic total transection enhances recovery of hindlimb locomotor movements $[10,13,51]$. We also demonstrated that graftrelated recovery is mediated in part by $5-\mathrm{HT}_{2 \mathrm{~A}}$ and $5-\mathrm{HT}_{7}$ receptors because application of their antagonists diminished the restored hindlimb locomotor movements [10, 13]. Constitutive activity in $5-\mathrm{HT}_{2}$ receptors is implicated in the recovery of locomotion after SCI $[25,52]$, and intrathecal application of a selective $5-\mathrm{HT}_{7}$ receptor antagonist during unrestrained locomotion in intact adult rats [4] blocks voluntary locomotion. Similar effects were obtained with $5-\mathrm{HT}_{2}$ antagonists [53].

Here, we hypothesize that the plastic changes in these receptors that occur after spinal cord injury might be affected by the restoration of 5-HT innervation from grafted 5-HT neurons so as to reverse or normalize these changes. This hypothesis is consistent with the findings that the presence of 5-HT or other ligands for these receptors can downregulate, upregulate, or desensitize these 5-HT receptors [54, 55]. We tested this hypothesis on identified MNs of the lumbar enlargement that innervate muscles with known actions during locomotion (ankle flexor (TA), extensor (GM), and tail elevator (ECM)), and we attempted to induce plasticity in the receptors on these MNs using thoracic spinal cord transection. We monitored the changes in receptor mRNA expression produced in these identified lumbar MNs at 1 month and 4 months after spinal cord transection, and we determined whether intraspinal grafting of embryonic serotonergic neurons in spinal rats reverses the effects of spinal total transection on expression of these genes. We show, for the first time, that intraspinal grafting of embryonic serotonergic neurons reverses injury-evoked changes in $5-\mathrm{HT}_{2 \mathrm{~A}}$ and $5-\mathrm{HT}_{7}$ receptor gene expression in the $\mathrm{MN}$ populations supplying hindlimb but not tail muscles. We propose that these changes may account for the effects of the grafts on neural plasticity responsible for locomotor recovery achieved by intraspinal grafting of embryonic raphe nuclei in paraplegic rats. A preliminary report of these findings has been published [56].

\section{Materials and Methods}

Experiments were performed on WAG (Wistar Albino Glaxo) 3-month-old female rats $(n=35)$ at the time of spinal cord injury. All procedures were conducted with care to minimize pain and suffering of animals with the approval of the First Local Ethics Committee in Poland, according to the principles of experimental conditions and laboratory animal care of European Union and the Polish Law on Animal Protection.

2.1. Spinal Cord Transection. Complete spinal cord transection (SCI) was performed $(n=23)$ at the Th9/10 level under deep anesthesia (isoflurane: $5 \%$ to induce and then maintained with $2 \%$ in oxygen $0.2-0.31 / \mathrm{min}$ and Butomidor: $0.05 \mathrm{mg} / \mathrm{kg}$ b.w.) as previously described [10]. To prevent the possibility of axonal regrowth through the cavity of the lesion, 1-2 mm of spinal cord tissue was aspirated using a glass pipette. Then, the muscles and fascia overlying the paravertebral muscles were closed in layers using sterile sutures, and the skin was closed with stainless steel surgical clips. After surgery, the animals received a nonsteroidal anti-inflammatory and analgesic treatment (s.c., Tolfedine 
$4 \mathrm{mg} / \mathrm{kg}$ b.w.) and antibiotics (s.c., Baytril $5 \mathrm{mg} / \mathrm{kg}$ b.w.; gentamicin $2 \mathrm{mg} / \mathrm{kg}$ b.w.) for the following 5-7 days. The bladder was emptied manually twice a day until the voiding reflex was reestablished.

2.2. Grafting of Embryonic 5-HT Cells. One month after SCI, nine out of 23 spinal rats were selected randomly for intraspinal grafting of embryonic serotonergic cells $\left(\mathrm{SCI}_{\mathrm{TR}}\right)$. Fourteen-day-old embryos (E14; E0-the day after mating) from time-pregnant female WAG rats were removed by Caesarean section and transferred to Hanks' buffered solution containing $0.5 \%$ glucose. A small piece of the embryonic caudal brainstem area containing the B1, B2, and B3 serotonergic regions was dissected under a microscope (for more details, see $[10,57])$.

At the same time, the spinal cord of a recipient rat (isoflurane anesthesia, $5 \%$ to induce and then maintained with $2 \%$ in oxygen $0.2-0.31 / \mathrm{min}$ ) was exposed by a small laminectomy at the Th11/12 vertebrae level (at least one segment below the total spinal cord transection), and a solid piece of embryonic tissue (approximately $2 \mu \mathrm{l}$ ) was injected by pressure into the spinal cord $1 \mathrm{~mm}$ below the pial surface through a sharpened micropipette attached to the Hamilton syringe. The micropipette was then slowly withdrawn to avoid graft movement. Control spinal rats $(n=11)$ were subjected to a sham grafting procedure where the operation was identical to that described above, but no tissue was injected into the spinal cord $[10,13,51]$.

2.3. Behavioral Assessment of Locomotor Ability in Spinal Rats. Before starting the procedure of collecting data for qRT-PCR analysis, two months after grafting (3 months after complete spinal cord transection), all the rats were subjected to behavioral testing to confirm the quality of their hindlimb plantar stepping. This was established in rats suspended above a treadmill with their forelimbs and thorax placed on a platform and with their hindlimbs touching the treadmill belt. To elicit hindlimb movements, a tail pinch was used. Stimulation of tail has been used for eliciting locomotion in many cases of complete spinal cord transection $[46,58]$ and has been used in all prior attempts to reveal locomotor recovery after brainstem neuron grafting $[10,13,57,59,60]$. The tail stimulus was adjusted by the experimenter to maximize the quality of plantar stepping. All the spinal grafted rats considered for the further investigation of gene expression in defined MNs or for immunohistochemistry of the spinal cord presented good plantar walking performance and were not different from those described in our previous paper $[10,13,51,57]$.

2.4. Implantation of EMG Electrodes. To evaluate the quality of hindlimb movements, we routinely use electromyography (EMG). In rats from the $\mathrm{SCI}_{4 \mathrm{~m}}$ group (three months after total transection) and in the rats from the $\mathrm{SCI}_{\mathrm{TR}}$ group (two months after intraspinal grafting), bipolar electrodes for EMG recordings were implanted under isoflurane anesthesia ( $5 \%$ to induce and then maintained with $2 \%$ in oxygen $0.2-0.31 / \mathrm{min}$ ) in Sol muscle (physiological extensor active during the stance phase of the step cycle) and TA muscle (physiological flexor active during the swing phase of the step cycle) of both hindlimbs. The electrodes were made of Teflon-coated stainless steel wire $(0.24 \mathrm{~mm}$ in diameter; AS633, CoonerWire Co., Chatsworth, CA, USA). The tips of the electrodes with $1-1.5 \mathrm{~mm}$ of the insulation removed were pulled through a cutaneous incision on the back of the animal, and each of the hook electrodes was inserted into the appropriate muscle and secured by a suture $[10,51,57]$. The distance between the electrode tips in the muscle was $1-2 \mathrm{~mm}$. The ground electrode was placed under the skin on the back of the animal in some distance from the hindlimb muscles. The connector with the other ends of the wires fixed to it, covered with dental cement (Spofa Dental, Prague, Czech Republic) and silicone (3140 RTV, Dow Corning), was secured to the back of the animal. After surgery, the animals received antibiotic treatment (Baytril, $5 \mathrm{mg} / \mathrm{kg}$ s.c.).

2.5. Tissue Preparation and Immunohistochemistry: Morphological Verification of Spinal Reactive Gliosis in Spinal Rats with and without the Graft. After testing the quality of locomotor hindlimb movements, three grafted rats and three spinal control rats without the graft were subjected to perfusion to prepare the spinal cord tissue for histological investigation of the graft condition and presence of inflammatory responses at the spinal level in which the MNs were collected.

For immunochemistry, the spinal cords were collected from the animals deeply anesthetized with pentobarbital and transcardially perfused with cold $0.1 \mathrm{M}$ phosphatebuffered saline (PBS), pH 7.2, for 2-3 min and subsequently with cold $4 \%$ paraformaldehyde in PBS for $15 \mathrm{~min}$. The spinal cords were postfixed and then cryoprotected gradually up to $30 \%$ sucrose in PBS, embedded in OCT, frozen on dry ice, and sectioned in a cryotome $(12 \mu \mathrm{m})$. The collected cross sections were immobilized on poly-L-lysine-covered glass slides and stored at $-20^{\circ} \mathrm{C}$.

The primary antibodies that were used in the immunohistochemistry were mouse antiglial fibrillary acidic protein (GFAP, 1:1000, BD Pharmingen) for astrocytes and mouse neuronal nuclear protein antibody (NeuN, 1:100 Millipore) for neuronal labeling. Isolectin B4 (FITC-conjugated, $20 \mu \mathrm{g} / \mathrm{ml}$, Sigma-Aldrich) was used for activated microglia detection. To identify 5-HT-positive fibers, rabbit anti-5-HT antibody (1:1000, ImmunoStar) was used. The Alexa Fluor secondary antibodies were used: 488conjugated donkey antibody against mouse IgG, 647conjugated goat antibody against mouse IgG, and 555conjugated donkey antibody against rabbit IgG, (1:1000 Invitrogen). Nuclei were stained with DAPI dye $(1 \mu \mathrm{g} / \mathrm{ml}$ in $\mathrm{H}_{2} \mathrm{O}$, Sigma-Aldrich).

For the immunostaining, frozen cross sections, after several rinses in PBS, were blocked in 10\% normal donkey or donkey/goat serum with $0.5 \%$ Triton X-100 in PBS at RT for $2 \mathrm{~h}$ and then incubated overnight at $4^{\circ} \mathrm{C}$ with primary antibodies followed by incubation with fluorophoreconjugated secondary antibodies for $2 \mathrm{~h}$ at room temperature. The specimens were coverslipped in fluorescence mounting medium (Dako) after several washes in PBS and examined 


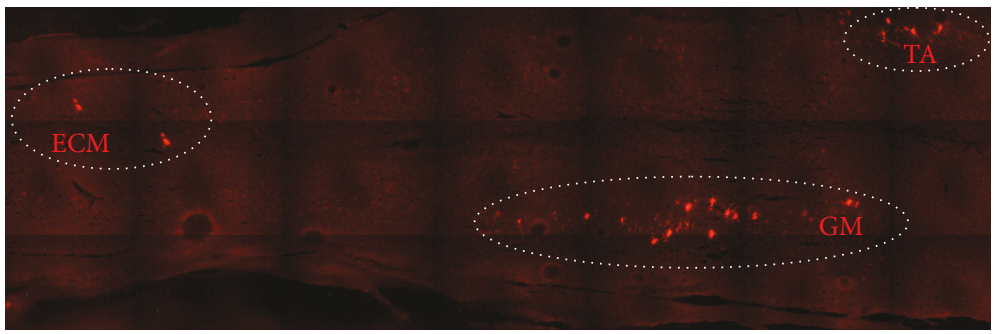

(a)

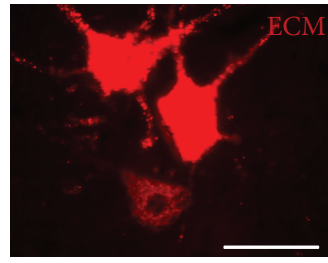

(b)

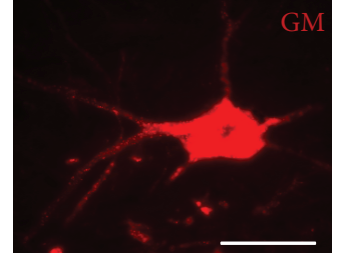

(c)

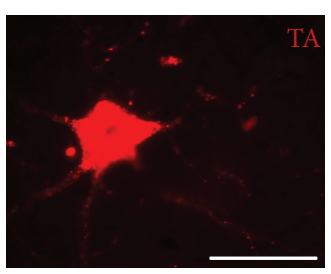

(d)

Figure 1: (a) Examples of labeled motoneurons (cholera toxin subunit B coupled with Alexa Fluor 555) innervating selected muscles: extensor caudae medialis (ECM) of the right side (b), gastrocnemius lateralis (GM) in the left hindlimb (c), and tibialis anterior (TA) in the right hindlimb (d). Scale bar: $50 \mu \mathrm{m}$.

on either a Zeiss Fluorescence Microscope Axio Imager.M2 or a Leica SP5 Laser Scanning Confocal Microscope.

2.6. Motoneuron Labeling. One week before the animal euthanasia, populations of MNs innervate the following muscles: TA of the right hindlimb, GM of the left hindlimb, and ECM of the right side of the tail were labeled by intramuscular injection by cholera toxin subunit B (CTB) coupled with Alexa Fluor 555 dye (see examples of CTB-labeled MNs innervating TA, GM, and ECM muscles in Figure 1). The TA and GM muscles were selected on the left and right sides to provide easy differentiation between the two MN pools innervating these two muscles when the same type of labeling was used in both of them. Also, the left ECM pool MN labeling (the most caudally localized) is a marker of the left side helping in identification of the GM MN pool. At the same time, the ECM and TA MN pools are separated with the most rostrocaudal distance. The ECM muscle was also selected because it plays a role in elevation of the tail, an indicator of functional recovery after spinal cord injury, according to the BBB score [61]. Animals were anesthetized using isoflurane $(5 \%$ to induce and then maintained with $2 \%$ in oxygen $0.2-0.31 / \mathrm{min}$ ), and proper muscles were exposed by small skin incisions enabling injection with $0.5 \%$ CTB using Hamilton syringe (TA and GM muscles $3 \times 15 \mu \mathrm{l}$ of CTB and ECM muscle $2 \times 20 \mu \mathrm{l}$ of CTB). The CTB injection was performed over a period of 2 minutes, the needle was slowly ( $2 \mathrm{~min}$ ) withdrawn, and the skin incision was closed.

\subsection{Htr2a and Htr7 Gene Expression Analysis}

2.7.1. Experiment Scheme. In order to examine the Htr2a and $\mathrm{Htr} 7$ gene expression in MNs innervating selected hindlimb and tail muscles, we performed experiments on 29 WAG female rats, in which specific motoneuron pools were labeled by injection of retrograde tracer molecules into a target muscle. Our investigations were performed on rats from four experimental groups: INT: intact $(n=12) ; \mathrm{SCI}_{\mathrm{TR}}$ : spinal cord injury followed by intraspinal transplantation of embryonic brainstem tissue containing serotonergic neurons $(n=6)$; $\mathrm{SCI}_{1 \mathrm{~m}}: 1$ month after spinal cord injury $(n=5) ; \mathrm{SCI}_{4 \mathrm{~m}}: 4$ months after spinal cord injury $(n=6)$-the time matched with the time of euthanasia of rats from the $\mathrm{SCI}_{\mathrm{TR}}$ group.

Animals from the $\mathrm{SCI}_{1 \mathrm{~m}}$ and $\mathrm{SCI}_{4 \mathrm{~m}}$ groups were subjected to a spinal cord total transection procedure performed at the thoracic level. Animals from the INT group were the control animals that were not subjected to any procedure. Animals from the $\mathrm{SCI}_{\mathrm{TR}}$ group received an intraspinal graft of 14-day-old rat embryonic brainstem one month after spinal cord total transection. Three months after intraspinal grafting in $\mathrm{SCI}_{\mathrm{TR}}$ group and four months after complete transection in rats of both groups, $\mathrm{SCI}_{\mathrm{TR}}$ and $\mathrm{SCI}_{4 \mathrm{~m}}$ (seven days after motoneuron tracer injection with cholera toxin subunit B coupled with Alexa Fluor 555) rats were transcardially perfused with PBS solution to remove any bloodborne 5-HT receptors, and the spinal cord was dissected and prepared for further analysis (animals from the $\mathrm{SCI}_{4 \mathrm{~m}}$ and $\mathrm{SCI}_{\mathrm{TR}}$ groups were euthanized 4 months after spinal cord total transection).

2.7.2. Laser Capture Microdissection (LCM) of Selected Motoneurons. Spinal cord tissue was collected from animals that were deeply anesthetized and transcardially perfused with PBS solution. Then, the spinal cords were immediately dissected and frozen by fast immersion in isopentane $\left(-80^{\circ} \mathrm{C}\right)$ and stored at $-80^{\circ} \mathrm{C}$ until future processing. Horizontal sections $(20 \mu \mathrm{m})$ of the lumbar-sacral spinal cord fragment were cut on the cryostat in $-20^{\circ} \mathrm{C}$ and mounted on PEN Membrane Frame Slides (Applied Biosystems). Slides were stored at $-80^{\circ} \mathrm{C}$ until future use.

Slides were dehydrated by immersion in increasing concentrations $(70 \%, 90 \%$, and $100 \%)$ of ethyl alcohol (ETOH) followed by immersion in xylene. Motoneuron collection was performed using an Arcturus Laser 
TABle 1: Description of assays used in real-time PCR.

\begin{tabular}{lcccc}
\hline Gene symbol & Reference number & Gene name & Assay ID & Amplicon length \\
\hline Ppia & NM_017101.1 & Cyclophilin A & Rn00690933_m1 \\
Htr2a & NM_017254.1 & Receptor 5-HT 2 A & Rn00568473_m1 & 71 \\
Htr7 & NM_022938.2 & Receptor 5-HT & Rn00576048_m1 & 85 \\
\hline
\end{tabular}

Microdissection System (Applied Biosystems). Tissue sections were photographed using a filter set for Alexa Fluor 555 to identify CTB-labeled MNs. Individual MNs were dissected using UV laser and collected on Cap Sure Macro LCM Caps (Applied Biosystems). After incubation in lysis buffer (Arcturus Pico Pure RNA Isolation Kit, Applied Biosystems) for 30 minutes, the samples were stored at $-80^{\circ} \mathrm{C}$ until future processing.

2.7.3. RNA Isolation. RNA was isolated using an Arcturus Pico Pure RNA Isolation Kit (Applied Biosystems) according to the manufacturer's instructions. Any residual genomic DNA was removed using supplementary DNAse I (RQ1 RNase-Free DNase, Promega) treatment. Three independent measurements of RNA concentration were obtained using NanoDrop (Thermo Scientific). RNA samples were pooled by mixing the same RNA amount isolated from one motoneuron population from all rats in a particular experimental group (i.e., equal amounts of RNA collected from the particular selected motoneuron populations in different rats in the same experimental group were pooled). RNA samples were stored at $-80^{\circ} \mathrm{C}$.

\subsubsection{Reverse Transcription PCR and cDNA Preamplification.} Reverse transcription PCR (RT-PCR) was performed in a $M J$ Mini Personal Thermal Cycler (Bio-Rad) using a High Capacity cDNA Reverse Transcription Kit (Applied Biosystems) according to the manufacturer's instructions $\left(10 \mathrm{~min}, 25^{\circ} \mathrm{C}\right.$; $120 \mathrm{~min}, 37^{\circ} \mathrm{C} ; 5 \mathrm{~min}, 85^{\circ} \mathrm{C}$; storage $4^{\circ} \mathrm{C}$ ) with use of $31 \mathrm{ng}$ of purified RNA as a sample. Synthesized cDNA was stored at $-20^{\circ} \mathrm{C}$ for future use.

Preamplification was performed to increase the number of cDNA copies to the level necessary for accurate detection in the real-time PCR reaction. cDNA was preamplified in MJ Mini Personal Thermal Cycler (Bio-Rad) using TaqMan PreAmp Master Mix Kit (Applied Biosystems). Reactions were conducted in standard conditions according to the preamplification kit manufacturer's instructions: $95^{\circ} \mathrm{C}$ for $10 \mathrm{~min}$; then 14 cycles: $95^{\circ} \mathrm{C}$ for $15 \mathrm{~s} ; 60^{\circ} \mathrm{C}$ for $4 \mathrm{~min}$.

2.7.5. Real-Time PCR. Expression of the Htr2a and Htr7 genes (encoding the $5-\mathrm{HT}_{2 \mathrm{~A}}$ and $5-\mathrm{HT}_{7}$ receptors, resp.) in the selected $\mathrm{MN}$ populations was measured by semiquantitative real-time PCR (qRT-PCR) using a Step One Plus (Applied Biosystems) thermocycler and TaqMan genespecific FAM/MGB assays (Applied Biosystems). Ppia gene encoding cyclophilin A was used as the housekeeping gene. The description of TaqMan assays used in the qRT-PCR reaction is shown in Table 1.

Reactions were run in triplicate for each sample and for each assay in $20 \mu \mathrm{l}$ reaction mix prepared in accordance with TaqMan Gene Expression Master Mix (Applied Biosystems) manufacturer recommendations. Reactions were run in standard, recommended by TaqMan Gene Expression Master Mix manufacturer conditions $\left(2 \mathrm{~min}, 50^{\circ} \mathrm{C} ; 10 \mathrm{~min}, 95^{\circ} \mathrm{C}\right.$; then 40 cycles: $15 \mathrm{~s}, 95^{\circ} \mathrm{C} ; 1 \mathrm{~min}, 60^{\circ} \mathrm{C}$ ). Relative expression levels of analyzed genes were then calculated using the comparative CT method.

2.8. Statistical Analysis. For comparison of results from two experimental groups, Student's $t$-test analysis was used after normal distribution was confirmed using Shapiro-Wilk test (Prism, GraphPad Software, La Jolla, CA). For statistical analysis of the results collected from qRT-PCR of more than two experimental groups that were expressed in relation to those established in INT rats, the nonparametric KruskalWallis test for multiple independent sample comparison followed by Conover post hoc (further adjusted by the Holm family-wise error rate (FWER) method and in one case the method of Benjamini-Hochberg false discovery rate (FDR) when the FWER method just approached significance) was used (http://astatsa.com/KruskalWallisTest/).

\section{Results}

3.1. Locomotor Ability in Spinal Rats. As we published before, the SCI rats $\left(\mathrm{SCI}_{1 \mathrm{~m}}\right.$ and $\left.\mathrm{SCI}_{4 \mathrm{~m}}\right)$ presented very limited hindlimb movements $[10,11,13,46,51]$. Usually, their hindlimbs were outstretched passively behind the hindquarters without any spontaneous hindlimb movement present and there was hardly any EMG activity recorded in the hindlimb flexor (TA) and extensor (Sol) muscles (Figure 2(a)). In contrast, the hindlimbs of the $\mathrm{SCI}_{\mathrm{TR}}$ rats moving in the home cage were abducted with partial flexion in the ankle joint or flexed at all joints with the foot plantar surface touching the ground, but without noticeable body weight support in spite presence of some EMG activity in hindlimb Sol and TA muscles (Figure 2(c)). Tail pinching in SCI rats suspended over a treadmill induced only irregular, limited hindlimb movements characterized by obvious lack of body weight support with no plantar stepping. EMG activity of hindlimb flexor and extensor muscles was irregular with lack of the long burst of Sol EMG activity related to the stance phase of the step cycle that is observed in normal locomotor activity of intact rats (Figure 2(b)). $\mathrm{In} \mathrm{SCI}_{\mathrm{TR}}$ rats suspended over the treadmill, tail pinch was effective to induce regular plantar hindlimb walking with nice regular EMG muscle activity with typical alternating pattern of EMG Sol versus TA bursts of activity and long burst of Sol related to the stance phase of step cycle in both hindlimbs (Figure 2(d)).

3.2. Morphological Verification of Reactive Gliosis in Spinal Rats with and without the Graft. As we published before 


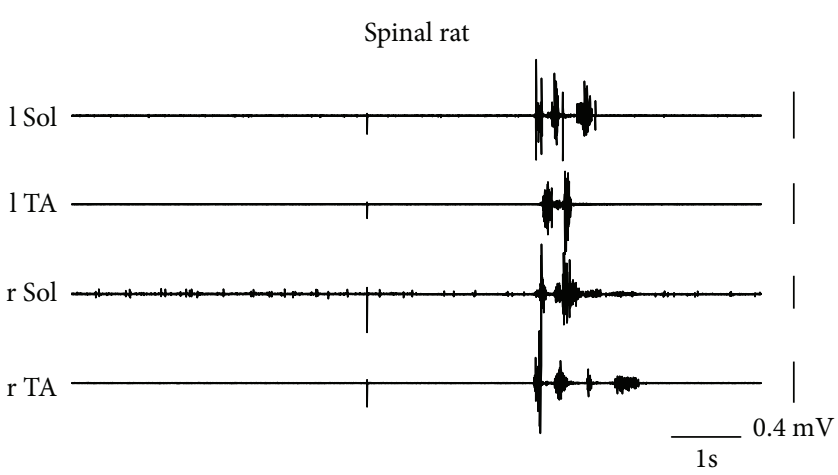

(a)

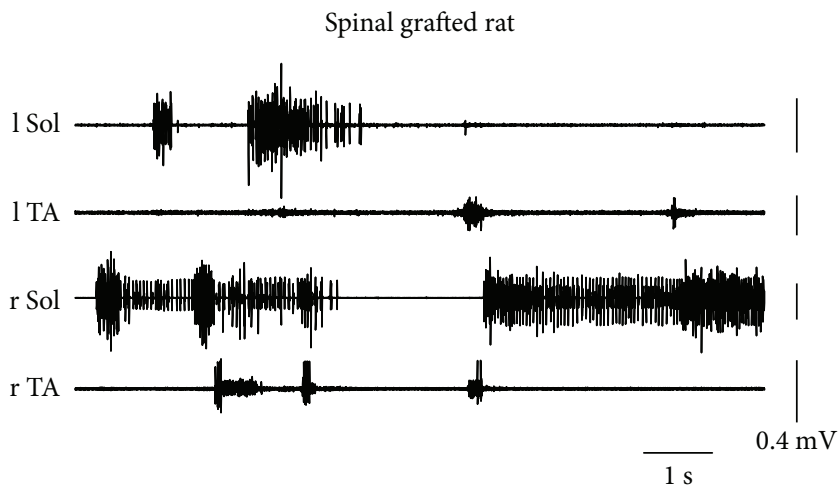

(c)

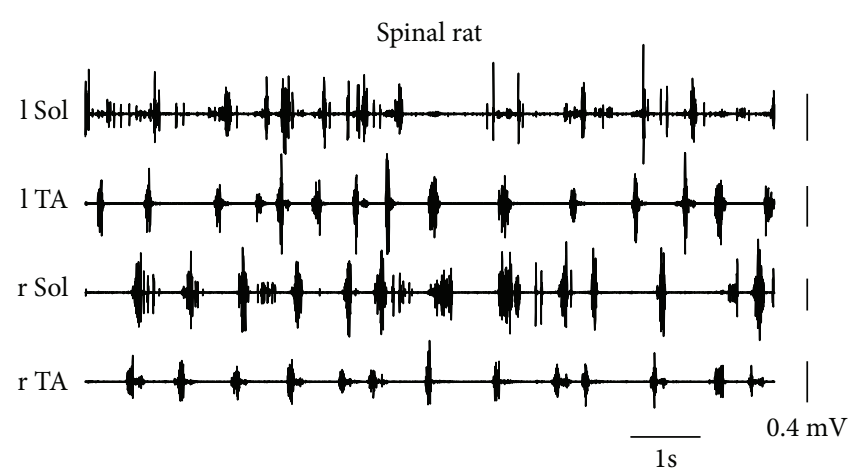

(b)

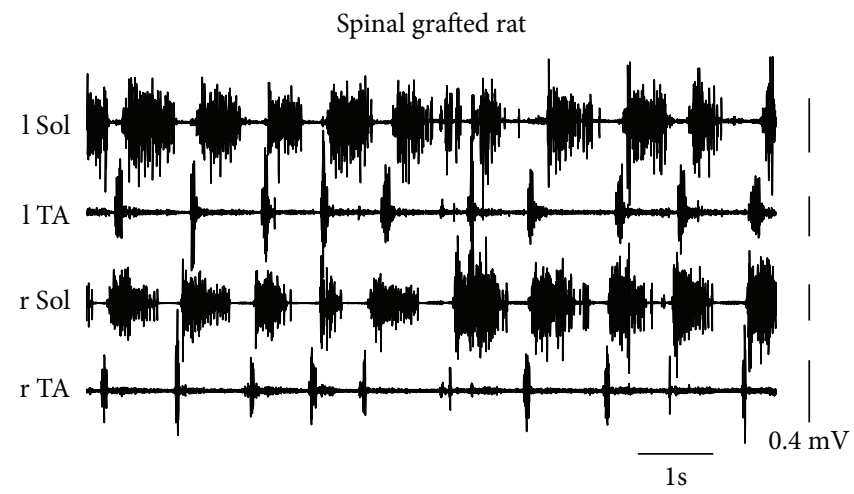

(d)

Figure 2: Examples of EMG recordings from hindlimb muscles of the spinal rats (a) and (b) and spinal grafted rat (c) and (d) during exploratory behavior in the home cage (a) and (c) and during locomotor-like hindlimb movements on a treadmill induced by tail pinching (b and d). Note that in spinal control rats during spontaneous movement in the home cage, the hindlimb muscles were usually silent but a brief episode of EMG activity could be induced by a sudden touch of the rat tail (a), while in the spinal grafted rats, the spontaneous EMG activity of Sol and TA muscles could be obtained without any external intervention (c) (for more details, see [10, 13, $51,57]$. Sol: soleus muscle; TA: tibialis anterior muscle; $1 / \mathrm{r}$ : left/right.

$[10,51,57]$, intraspinally grafted $5-\mathrm{HT}$ neurons survive the grafting procedure and their axons grow into the distal part of the host spinal cord, spreading caudally for a considerable distance below the total transection. Figure 3(b) shows a representative example of fetal grafted tissue located in the spinal cord one/two segments below the total transection of the spinal grafted rat. The sham-operated spinal $\mathrm{SCI}_{4 \mathrm{~m}}$ rats do not possess any 5-HT innervation in the spinal cord below the total transection (Figure 3(a)). Here, we also verified the presence of activated microglia and astrocytes in the spinal cord below transection in spinal rats with $\left(\mathrm{SCI}_{\mathrm{TR}}\right)$ and without the graft $\left(\mathrm{SCI}_{4 \mathrm{~m}}\right)$ long after the injury (4 months). While there was moderate microglia activation detectable within white matter and virtually no activation in grey matter at Th13/L1 (the level of a real or sham grafting), we were not able to detect any sign of inflammation at L4/L5 in any of the animals, regardless of whether they were sham or grafted ones (Figure 3 left and middle panels). Moreover, while we identified a slightly increased number of astrocytes in ventral horns at the grafting level compared to control, the same numbers of astrocytes were observed at $\mathrm{L} 4 / \mathrm{L} 5$ in both $\mathrm{SCI}_{4 \mathrm{~m}}$ and $\mathrm{SCI}_{\mathrm{TR}}$ rats. However, none of the detected astrocytes showed the morphology of reactive cells (Figure 3, right panel). Thus, we assumed that 4 months after transplantation of embryonic tissue, there is no inflammatory reaction in the ventral horn at and below of L4/L5 spinal cord levels, where our samples were taken. This finding demonstrates that a role for inflammation in changes in 5-HT receptors such as previously suggested after sacral spinal cord injury [43] does not apply in our case.

\subsection{Htr2a and Htr7 Gene Expression in MNs of Intact Adult} Rats. The relative abundance of the distinct mRNAs was established by the minimal number of amplification cycles necessary to detect a given mRNA and was presented at graph as $1 / \Delta \mathrm{Ct}$ value. In all analyzed populations of MNs innervating the TA, GM, and ECM muscles, expression of $\mathrm{Htr} 2 \mathrm{a}$ and $\mathrm{Htr} 7$ genes (encoding $5-\mathrm{HT}_{2 \mathrm{~A}}$ and $5-\mathrm{HT}_{7}$ receptors, resp.) was detectable and expression of $\mathrm{Htr} 2 \mathrm{a}$ gene in all analyzed motoneurons was significantly higher (Student's $t$-test $p<0.0001)$ than expression of gene encoding $5-\mathrm{HT}_{7}$ serotonin receptor (Figure 4).

3.4. Htr2a Gene Expression in MNs. In comparison to INT rats, in $\mathrm{SCI}_{1 \mathrm{~m}}$ rats, the Htr2a gene expression was reduced by $\sim 60 \%$ in TA MNs (nonparametric Kruskal-Wallis test (df: $3, p=0.015$ ) with Conover post hoc test $p<0.001$ ) and by $\sim 50 \%$ in the GM MNs (nonparametric Kruskal-Wallis test 

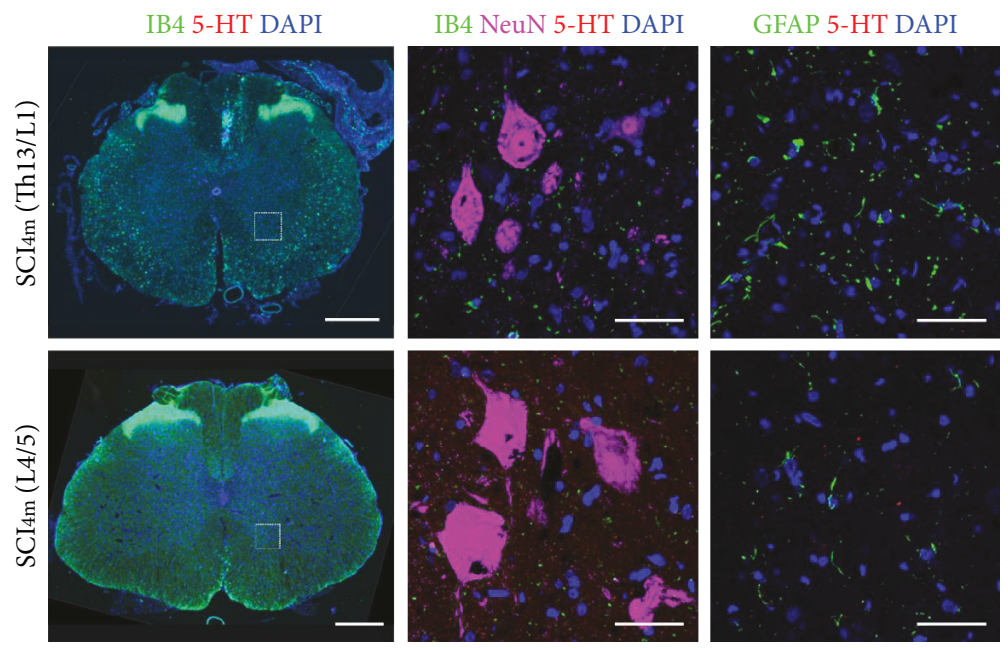

(a)
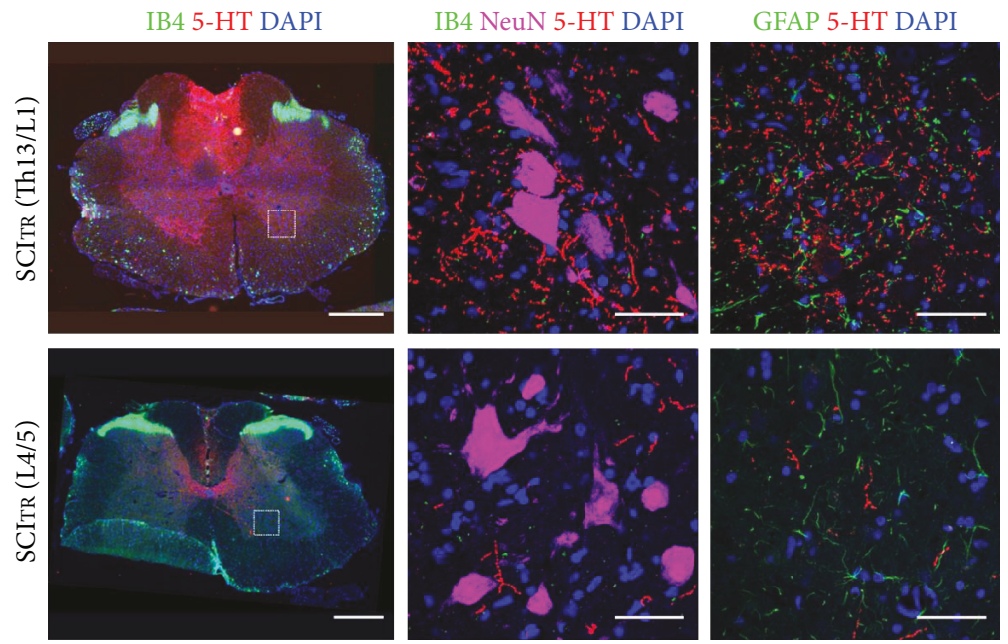

(b)

FIGURE 3: Immunofluorescent detection of inflammatory response in control $\mathrm{SCI}_{4 \mathrm{~m}}$ (a) and transplanted SCI $\mathrm{TR}_{\mathrm{TR}}$ (b) rats at 4 months after total spinal transection and 3 months after transplantation (sham grafting in $\mathrm{SCI}_{4 \mathrm{~m}}$ ). The first panel shows general view of spinal cord cross section labeled with isolectin B4 (IB4) to visualize activated microglia in low power; the next two panels show boxed area labeled with IB4 (green; left and middle panel) for microglia and GFAP (green; right panel) for astrocytes, reimaged using confocal microscope. Note grafted tissue at Th13/L1 and serotonin-positive fibers (5-HT, red) located closely to ventral horn motoneurons (NeuN; purple) at L4/L5. Representative images: scale bar: $500 \mu \mathrm{m}$ and $50 \mu \mathrm{m}$ in low- and high-power images, respectively.

(df: $3, p=0.019$ ) with Conover post hoc test $p<0.01$ ) and increased by $103 \%$ in ECM MNs (nonparametric KruskalWallis test (df: $3, p=0.015$ ) with Conover post hoc $p<$ 0.0001 ) when normalized to the Htr2a gene expression in MNs of INT animals (Figure 5).

In $\mathrm{SCI}_{4 \mathrm{~m}}$ rats, the Htr2a gene expression was also lower than in INT rats ( $45 \%$ of INT) in TA MNs (Conover post hoc test $p<0.001$ ) and GM MNs (Conover post hoc test $p<$ $0.05)$. There was also a small difference in gene expression in $\mathrm{SCI}_{4 \mathrm{~m}}$ rats in comparison to $\mathrm{SCI}_{1 \mathrm{~m}}$ rats (Conover post hoc test $p<0.05)$ in MNs of both TA and GM muscles. In $\mathrm{SCI}_{4 \mathrm{~m}}$, the Htr2a gene expression in the ECM MNs decreased by $\sim 44 \%$ (Conover post hoc $p<0.001$ ) in comparison to the gene expression level measured in $\mathrm{SCI}_{1 \mathrm{~m}}$ rats. Expression of the Htr $2 a$ gene in TA and GM MNs of $\mathrm{SCI}_{4 \mathrm{~m}}$ rats was still much lower than expression of this gene in INT rats (Figure 5).
Intraspinal grafting of embryonic brainstem serotonergic neurons reversed to some extent changes in the Htr2a gene expression observed in the TA and GM MNs of $\mathrm{SCI}_{1 \mathrm{~m}}$ rats (Figure 5). Expression of the Htr2a gene in TA and in GM MNs in $\mathrm{SCI}_{\mathrm{TR}}$ rats was significantly higher by $112 \%$ and $110 \%$, respectively, than that in $\mathrm{SCI}_{1 \mathrm{~m}}$ (Conover post hoc test $p<0.001$ for both $\mathrm{MN}$ populations) and by $52 \%$ and $93 \%$, respectively, than that in $\mathrm{SCI}_{4 \mathrm{~m}}$ (Conover post hoc test $p<0.05$ and $p<0.01$, resp., for both $\mathrm{MN}$ populations). However, Htr2a gene expression remained $14 \%$ lower in comparison to MNs of INT TA (Conover post hoc test $p<$ $0.05)$ but in the GM MNs was restored to the level of INT (Conover post hoc test $p>0.05$ ). The expression of the $\mathrm{Htr2a}$ gene in ECM MNs of $\mathrm{SCI}_{\mathrm{TR}}$ rats remained increased by $\sim 25 \%$ in comparison to that in MNs of INT rats (Conover post hoc test $p<0.001$ ). 


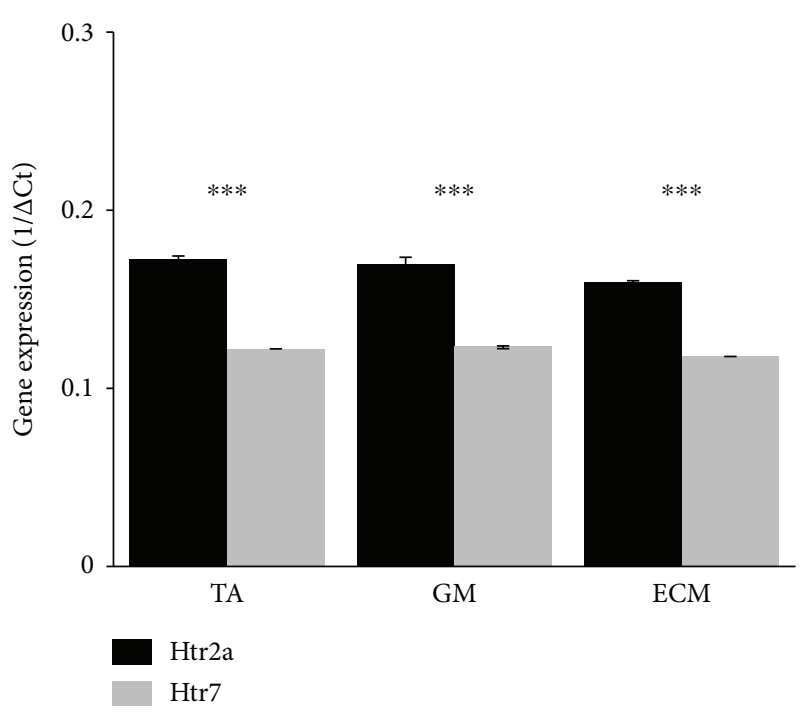

Figure 4: Expression level of Htr2a and Htr7 genes (encoding 5$\mathrm{HT}_{2 \mathrm{~A}}$ and $5-\mathrm{HT}_{7}$ receptors, resp.) in motoneuron populations innervating TA, GM, and ECM muscles in intact adult rats. Expression levels of Htr2a and Htr7 genes were normalized to the expression level of the constitutively active Ppia (cyclophyline A) gene and was presented as the $1 / \Delta \mathrm{Ct}$ value of the analyzed genes. Student's $t$-test ${ }^{* * *} p<0.0001$. Data are presented as mean \pm standard deviation (mean $\pm \mathrm{SD}$ ). TA: tibialis anterior muscle; GM: gastrocnemius muscle; ECM: extensor caudae medialis muscle.

3.5. Htr7 Gene Expression in MNs. In $\mathrm{SCI}_{1 \mathrm{~m}}$ rats, the Htr7 gene expression was reduced by $\sim 22 \%$ in TA MNs (nonparametric Kruskal-Wallis test (df: $3, p=0.015$ ) with Conover post hoc test $p<0.001$ ), by $\sim 50 \%$ in GM MNs (nonparametric Kruskal-Wallis test (df: $3, p=0.022$ ) with Conover post hoc test $p<0.05$ ), and by $\sim 20 \%$ in ECM MNs (nonparametric Kruskal-Wallis test (df: 3, $p=0.025$ ) with Conover post hoc test $p<0.001$ ) when normalized to the Htr 7 gene expression in MNs of INT animals (Figure 6).

In $\mathrm{SCI}_{4 \mathrm{~m}}$ rats, the $\mathrm{Htr} 7$ gene expression was also lower than in INT rats in TA MNs (Conover post hoc test $p<$ 0.05 ) and in GM MNs (Conover post hoc test $p<0.01$ ). There was also a small increase in gene expression in $\mathrm{SCI}_{4 \mathrm{~m}}$ rats in comparison to $\mathrm{SCI}_{1 \mathrm{~m}}$ rats (Conover post hoc test $p<0.05)$ in TA MNs but remained significantly lower in comparison to that of INT $(p<0.01)$. In MNs of GM muscle, $H t r 7$ gene expression was unchanged (Conover post hoc test $p>0.05)$ in comparison to that of $\mathrm{SCI}_{1 \mathrm{~m}}$ rats but remained lower in comparison to that of INT (Conover post hoc test $p<0.01)$. In $\mathrm{SCI}_{4 \mathrm{~m}}$, the Htr7 gene expression in the ECM MNs increased by $\sim 12 \%$ (Conover post hoc test $p<0.05$ ) in comparison to the gene expression level measured in $\mathrm{SCI}_{1 \mathrm{~m}}$ rats (Figure 6).

Intraspinal grafting of embryonic brainstem serotonergic neurons reversed changes in the $\mathrm{Htr} 7$ gene expression observed in the TA and GM MNs of $\mathrm{SCI}_{1 \mathrm{~m}}$ rats (Figure 6). Expression of the Htr7 gene in the TA MNs (nonparametric Kruskal-Wallis test (df: $3, p=0.015$ ) with post hoc Conover method for multiple comparisons $p<0.001$ ) and in the GM MNs (nonparametric Kruskal-Wallis test $p=0.022$ and
Conover post hoc adjusted with FDR method for multiple comparisons $p<0.05)$ in $\mathrm{SCI}_{\mathrm{TR}}$ rats was higher than that in the INT rats. Expression of the $\mathrm{Htr} 7$ gene in $\mathrm{SCI}_{\mathrm{TR}}$ significantly increased by $\sim 109 \%$ (Conover post hoc $p<0.01$ ) and $\sim 215 \%$ (Conover post hoc test $p<0.001$ ) in the TA and GM MNs, respectively, in comparison to the Htr7 gene expression in the $\mathrm{SCI}_{1 \mathrm{~m}}$ and by $\sim 86 \%$ (Conover post hoc $p<0.001$ ) and $\sim 215 \%$ (Conover post hoc test $p<0.001$ ) in the TA and GM MNs, respectively, in comparison to the $\mathrm{Htr} 7$ gene expression in $\mathrm{SCI}_{4 \mathrm{~m}}$ rats. On the other hand, in the ECM MNs, expression of the Htr7 gene in the $\mathrm{SCI}_{\mathrm{TR}}$ rats was not different in comparison to the Htr7 expression in the $\mathrm{SCI}_{4 \mathrm{~m}}$ rats (nonparametric Kruskal-Wallis (df: 3, $p=0.025$ with Conover post hoc $p=0.81)$ ).

\section{Discussion}

In our previous papers, we demonstrated that intraspinal grafting of embryonic neurons destined to form the descending 5-HT system of the rat brain stem effectively restores coordinated plantar stepping in adult spinal rats $[10,13,51$, 57]. We also demonstrated that such recovery is mediated by $5-\mathrm{HT}_{2 \mathrm{~A}}$ and $5-\mathrm{HT}_{7}$ serotonergic receptors $[10,13]$.

In the present paper, we confirmed expression of the $H t r 2 a$ and $H t r 7$ genes in MN populations of intact and paraplegic rats. We showed for the first time that intraspinal transplantation of rat E14 embryo brainstem containing serotonergic neurons increases expression of these genes in the TA and GM hindlimb MNs in comparison to ungrafted spinal animals. We found that $5-\mathrm{HT}_{7}$ receptor mRNA was decreased at 1 month and 4 months after spinal cord injury in all 3 types of MNs. In the presence of the grafts, $5-\mathrm{HT}_{7}$ mRNA levels increased above those at 1 and 4 months and were significantly different from the intact condition in TA, GM, and ECM MNs. The graft tended to reverse the decrease in $5-\mathrm{HT}_{7}$ receptor mRNA in TA and GM MNs, with a sustained increase after 4 months in the grafted rats. The grafts did not have such an effect in ECM (tail) MNs. One month after SCI, $5-\mathrm{HT}_{2 \mathrm{~A}}$ receptor mRNA decreased in flexor and extensor MNs, while it increased in tail MNs. Flexor and extensor MNs had decreased 5- $\mathrm{HT}_{2 \mathrm{~A}}$ mRNA after 4 months, while $5-\mathrm{HT}_{2 \mathrm{~A}} \mathrm{mRNA}$ in the tail MNs decreased in comparison to that observed one month after SCI but remained slightly higher than that in INT. Grafting resulted in 5$\mathrm{HT}_{2 \mathrm{~A}}$ mRNA levels that did not differ from the intact condition in GM MNs, but 5- $\mathrm{HT}_{2 \mathrm{~A}}$ mRNA expression continued to be slightly downregulated in TA MNs and upregulated in ECM MNs. It is possible to conclude that the presence of the grafts tended to normalize the levels of 5-HT receptor mRNA in limb muscle MNs, as predicted by our hypothesis, but not in MNs of tail muscle. A possible mechanism for the effect of the grafts might be that increased Htr2a gene expression may be a consequence of the increased presence of 5-HT derived from the graft, which can occur in some cells [62]. The mechanism for regulation of Htr2a gene expression in MNs of different types may vary. This is a suitable topic for further research.

Our data showing $5-\mathrm{HT}_{2 \mathrm{~A}}$ mRNA upregulation in ECM is similar to findings on receptor protein upregulation in 


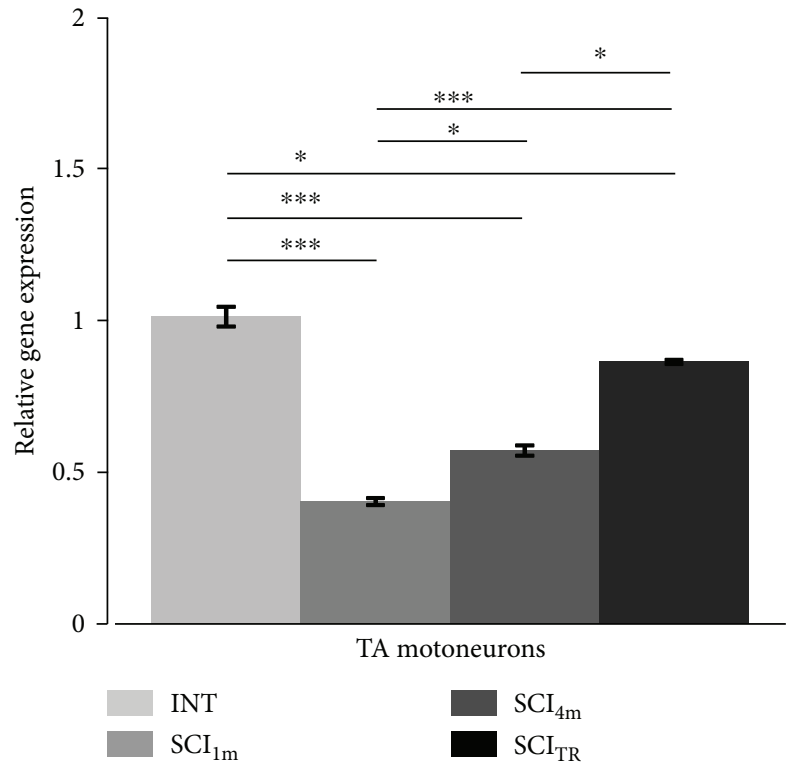

(a)

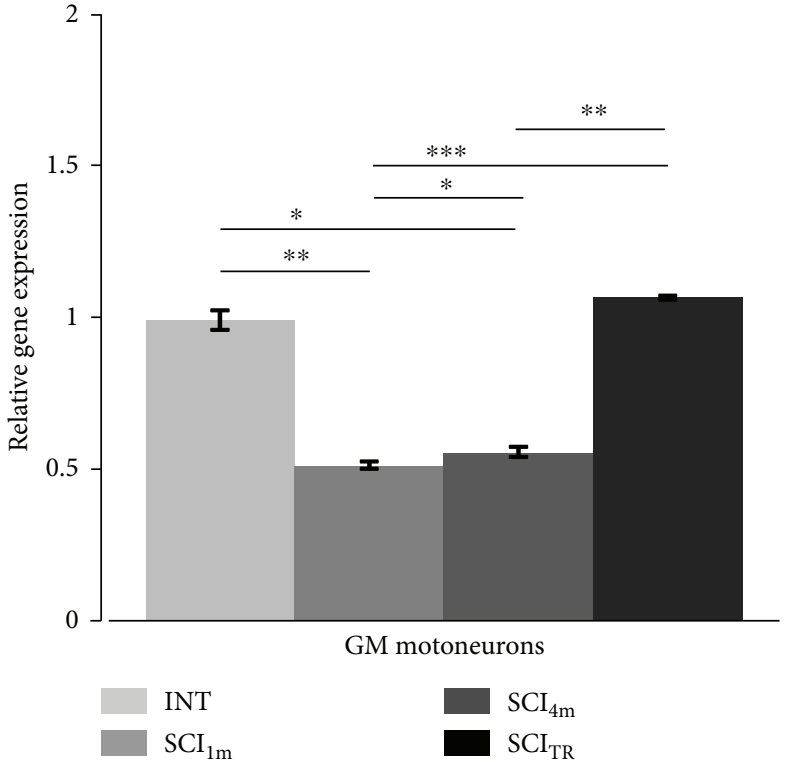

(b)

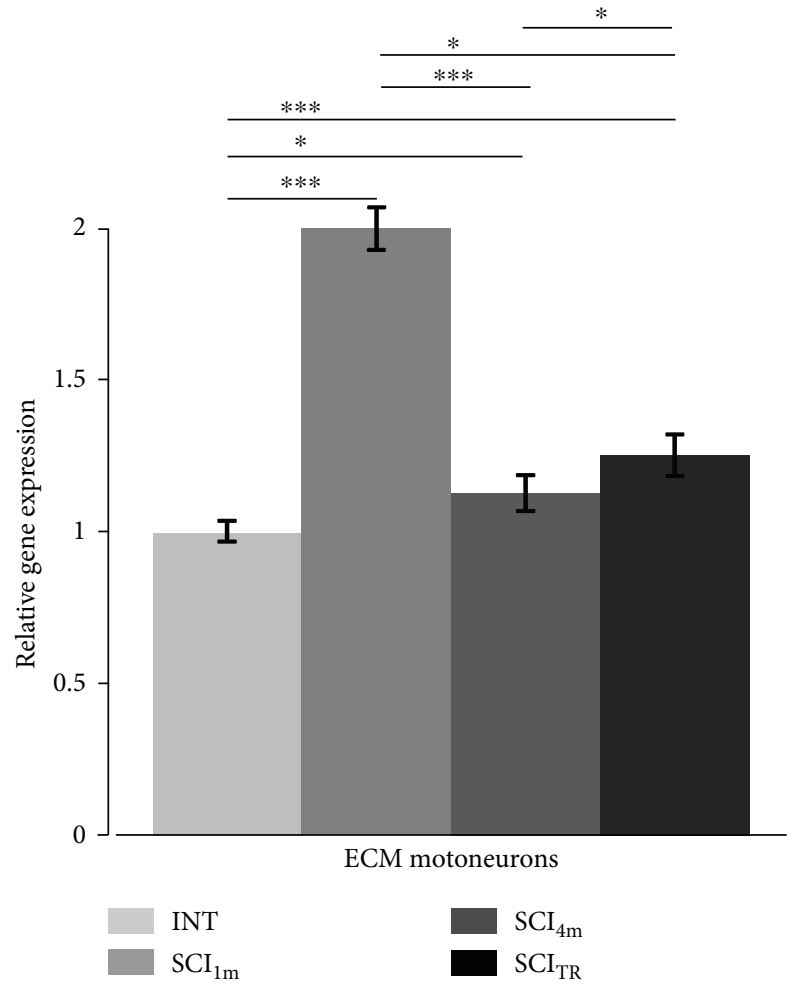

(c)

Figure 5: Changes in the Htr2a gene expression in MNs innervating the TA (a), GM (b), and ECM (c) muscles in rats one and four months after total spinal cord transection and in spinal rats with a graft of 14-day-old rat embryonic brainstem tissue containing serotonergic neurons. INT: intact rats; $\mathrm{SCI}_{1 \mathrm{~m}}$ : rats 1 month after spinal cord transection; $\mathrm{SCI}_{4 \mathrm{~m}}$ : rats 4 months after spinal cord transection; $\mathrm{SCI}_{\mathrm{TR}}$ : rats 4 months after spinal cord transection with a graft; TA: tibialis anterior muscle; GM: gastrocnemius muscle; ECM: extensor caudae medialis muscle. Data normalized to the expression of Htr2a gene in MNs of INT rats are presented as mean \pm SD (standard deviation). Nonparametric Kruskal-Wallis test with Conover post hoc method for multiple comparison $\left({ }^{*} p<0.05 ;{ }^{* *} p<0.01 ;{ }^{* * *} p<0.001\right)$.

more distal tail muscle MNs [63-65]. In MNs innervating hindlimb muscles, 5- $\mathrm{HT}_{2 \mathrm{~A}}$ receptor protein levels have been observed to be upregulated $4-6$ weeks after contusive SCI $[66,67]$. Protein levels for this receptor have not been examined at later time points after injury. Absence of an increase in Htr2a gene expression after total transection observed here is consistent with in situ hybridization data obtained by Ung and colleagues showing a clear tendency 


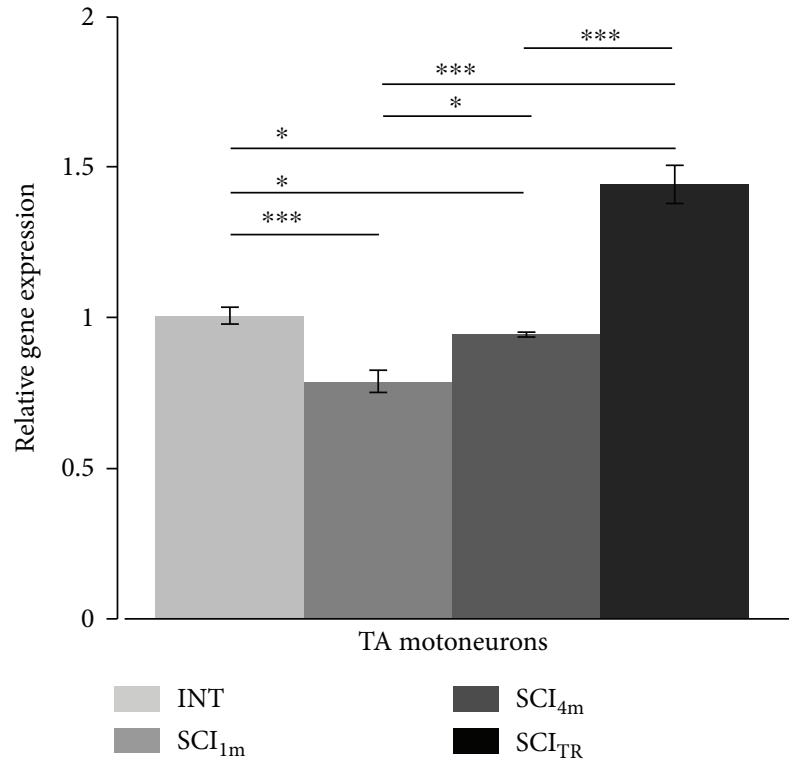

(a)

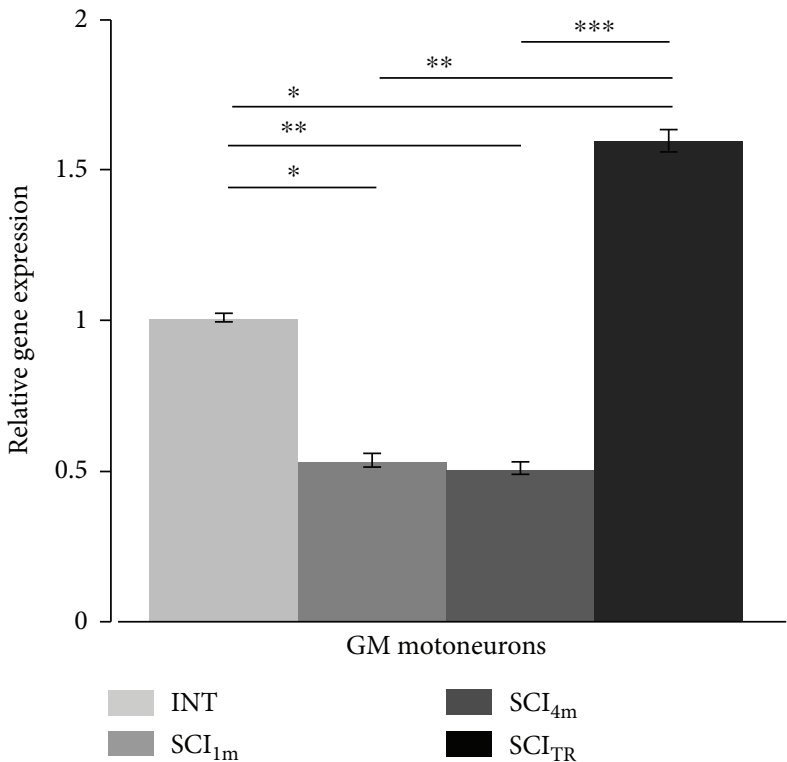

(b)

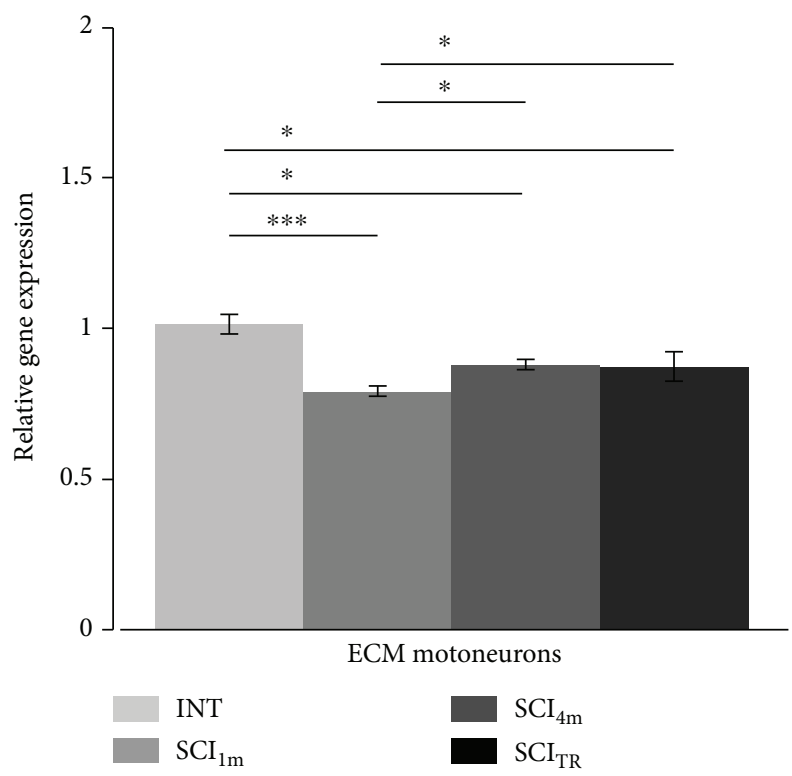

(c)

Figure 6: Changes in the Htr7 gene expression in MNs innervating TA (a), GM (b), and ECM (c) muscles in rats one and four months after total spinal cord transection and in spinal rats with a graft of 14-day-old rat embryonic brainstem tissue containing serotonergic neurons. INT: intact rats; $\mathrm{SCI}_{1 \mathrm{~m}}$ : rats 1 month after spinal cord transection; $\mathrm{SCI}_{4 \mathrm{~m}}$ : rats 4 months after spinal cord transection; $\mathrm{SCI}_{\mathrm{TR}}$ : rats 4 months after spinal cord transection with a graft; TA: tibialis anterior muscle; GM: gastrocnemius muscle; ECM: extensor caudae medialis muscle. Data normalized to the expression of Htr7 gene in MNs of INT rats are presented as mean \pm SD (standard deviation). Nonparametric Kruskal-Wallis test with Conover post hoc method for multiple comparison $\left({ }^{*} p<0.05 ;{ }^{* *} p<0.01 ;{ }^{* * *} p<0.001\right)$.

of $5-\mathrm{HT}_{2 \mathrm{~A}}$ mRNA to decrease in the ventral horn of lumbar segments 28 days after spinal cord transection in adult mice [68]. Our data on $5-\mathrm{HT}_{2 \mathrm{~A}}$ receptor $\mathrm{mRNA}$ are not predictive of the increase in $5-\mathrm{HT}_{2 \mathrm{~A}}$ receptor protein. Maier et al. [69] reviewed the common observation that mRNA and protein expression can be uncorrelated. They conclude that the major posttranslational factor influencing mRNA-protein correlation is the individual half-life of proteins. Our observation of a decrease in mRNA expression at times when increases in protein expression occur $[66,67]$ can be explained by the relative half-life of the mRNA and the 5$\mathrm{HT}_{2 \mathrm{~A}}$ receptor protein. In situ hybridization results [68] are consistent with a decrease in Htr2a gene expression after spinal cord injury in the ventral horn (28 days in their case and one month and 4 months in our case). In the paper by Chopek et al. [42], the samples were taken 3 months after injury. Since mRNA expression is not maintained in a steady state [69], some fluctuation in mRNA expression over time is 
to be expected. For example, in laser-captured phrenic motoneurons [70], mRNA for $5-\mathrm{HT}_{2 \mathrm{~A}}$ receptors was upregulated 14 days after cervical hemisection, but had returned to normal or below at 21 days. Fuller et al. [27], in contrast, found upregulation of $5-\mathrm{HT}_{2 \mathrm{~A}}$ protein after 7-14 days in the same preparation (cervical hemisection). The decrease in Htr2a gene expression may be an autoregulatory response to increased receptor density [71].

Chopek and others [42] found significant increases in $\mathrm{Htr} 2 a$ gene expression in motoneurons innervating hindlimb flexor and extensor muscles after spinal cord transection. This is not surprising given the frequent absence of correlation between gene and protein expression after injury. What might account for the differences between our findings and those of Chopek et al? They might be an effect of different selection of motoneurons for analysis. We compared MNs innervating TA with those innervating GM based upon the fact that these muscles have comparable composition of the three types of motor units, but they are different in function (extensor versus flexor). Chopek and others collected MNs innervating both soleus and gastrocnemius lateralis muscles to the extensor pool and MNs innervating extensor digitorum longus and tibialis anterior muscles to the flexor pool. Soleus is a typical slow muscle, and extensor digitorum longus is a typical fast muscle, so including these MNs in their extensor and flexor pools, respectively, may have influenced the results. MNs of different sizes may express 5- $\mathrm{HT}_{2 \mathrm{~A}}$ receptors differently, and they react differently to spinal cord injury [72]. Moreover, Chopek and others [42] use SDHA as the reference gene for qPCR analysis, which may have influenced the results, because expression of this gene may be altered by spinal cord injury. This is the case after disuse in microgravity, and it appears to induce changes in SDHA expression differently in motoneurons of different sizes [73, 74]. We selected the Ppia gene after Navarrett and others [75], who verified it as suitable for use in spinal cord tissue after injury. We also eliminated any effects of 5-HT receptors in blood [76] by perfusing the rat with PBS before dissecting the spinal cord and further preparation for laser capture of the motoneurons, whereas this was not done by others who observed an increase in 5- $\mathrm{HT}_{2 \mathrm{~A}}$ mRNA $[42,43]$. In the $\mathrm{Di}$ Narzo et al. [43] study, the sample was taken from the sacral cord and was not limited to motoneurons. Another possible explanation for the differences between our observations on $5-\mathrm{HT}_{2 \mathrm{~A}}$ mRNA levels after injury and those of Chopek et al. [42] and Di Narzo et al. [43] is that they used Sprague-Dawley rats, while WAG (Wistar Albino Glaxo) rats were used in our study.

Di Narzo et al. [43] described recently that in rat spinal cord, the mRNA expression of Htr2c gene is influenced by inflammation caused by total transection at the sacral level $(0.6 \mathrm{~mm}$ below and above the SCI). Our analysis of the inflammatory responses in the spinal cord of spinal rats with and without a graft revealed that in the ventral horn of the lumbar segments $(6 \mathrm{~mm}$ below the graft site-the shortest distance below the graft that MNs of TA and GM muscles were collected), there was no increased level of astrocytes and no presence of activated microglia. Thus, inflammation induced by intraspinal grafting is not likely to be responsible for the observed changes in Htr2a and Htr7 gene expression.

There is good evidence for constitutive activity in $5-\mathrm{HT}_{2}$ receptors in sacral MNs after S2 spinal cord injury (reviewed in [14]), but the evidence that this is true in MNs innervating limb muscles is less complete. The degree of constitutive activity of 5- $\mathrm{HT}_{2 \mathrm{~A}}$ receptors is thought to be dependent upon mRNA expression [75]. The reduction in mRNA after SCI may be interpreted as an indication of decreased constitutive activity in both $5-\mathrm{HT}_{2 \mathrm{~A}}$ and $5-\mathrm{HT}_{7}$ receptors. Our finding that limb motoneuron $5-\mathrm{HT}_{2 \mathrm{~A}}$ and $5-\mathrm{HT}_{7}$ mRNA expression is increased by the grafts could therefore reflect an increase in constitutive activity in these receptors. Whether this can account for the efficacy of the grafts for improving locomotor recovery in paraplegic rats will require further investigation. These results suggest that the mechanisms regulating 5-HT receptor mRNA expression in limb and tail MNs after SCI might be different.

Our results showing $5-\mathrm{HT}_{7}$ receptor mRNA upregulation after grafting provides support for the suggestion that the graft improves locomotion by increasing the role of this receptor in these MNs. Both 5- $\mathrm{HT}_{2 \mathrm{~A}}$ and 5- $\mathrm{HT}_{7}$ receptors are expressed in phrenic MNs, and both receptors facilitate spinal motor plasticity $[77,78]$. Their coexistence results in mutual crosstalk inhibition (Fuller and Mitchell respiratory neuroplasticity) due to the downstream effects induced by $\mathrm{Gq}\left(5-\mathrm{HT}_{2 \mathrm{~A}}\right)$ and Gs $\left(5-\mathrm{HT}_{7}\right)$ activation. The details of this crosstalk inhibition are not well defined, but this factor needs to be taken into account if the function of neurons expressing both these $G$ protein receptors is to be understood. In the case of limb motoneurons, it is possible that such crosstalk inhibition could result in mutual downregulation of receptor expression. Further investigations of the effects of $5-\mathrm{HT}_{7}$ receptors on limb motoneurons are warranted. A description of the mechanisms involved in the increased expression of RNAs for both receptors induced by the grafts will require further investigation.

$5-\mathrm{HT}_{7}$ receptors appear to be expressed in limb MNs, but their role in controlling motoneuron function has not been established. Zhang [79] found that a $5-\mathrm{HT}_{7}$ receptor agonist produced depolarization when applied iontophoretically onto lumbar MNs in cat spinal cord. MN excitability might be increased if $5-\mathrm{HT}_{7}$ receptors mediated a reduction in the afterhyperpolarization in limb MNs, which appears to be the case in trigeminal MNs [19]. Limb MN AHPs are reduced by iontophoretically applied 5-HT [80], but the receptor responsible for this effect has not been determined. These issues need to be investigated, along with the possibility of inhibitory crosstalk between $5-\mathrm{HT}_{2 \mathrm{~A}}$ and $5-\mathrm{HT}_{7}$ receptors which occurs in phrenic motoneurons $[77,78]$, when both receptors are present in the same cell.

\section{Conclusion}

Our results indicate that thoracic spinal cord transection leads to changes in Htr2a and Htr7 gene expression, whereas transplantation of embryonic serotonergic neurons reverses these changes in MNs innervating hindlimb muscles but not those innervating the tail muscle. These differences in $H \operatorname{tr} 2 a$ and $H t r 7$ gene expression between MNs innervating 
hindlimb and tail muscles can be a result of the distance from the graft to the motoneurons. The fibers of grafted 5-HT neurons do not extend farther than to the level of L4-L5 lumbar segments [10, 57], so motoneurons innervating the ECM muscle may not be supplied by serotonergic innervation of graft origin. Alternatively, it may be that motoneurons that innervate tail muscles have unique adaptations to spinal injury and the effects of intraspinal grafts of 5-HT neurons, such as reliance on constitutive activity of $5-\mathrm{HT}_{2}$ receptors after spinal cord injury. Increased Htr2a and Htr7 gene expression induced by the graft could restore motoneuron excitability and lead to improved motor function, such as we observed in the grafted rats [10,57]. Here, we show for the first time that changes in gene expression induced by the graft may account for this recovery.

\section{Data Availability}

All data used in this study are included in the article. Any additional information required will be provided upon request to the corresponding author.

\section{Conflicts of Interest}

The authors declare that there is no conflict of interest regarding the publication of this paper.

\section{Acknowledgments}

This work was supported by grants from the Polish National Science Centre (UMO-2013/09/B/NZ4/02885) to Urszula Sławińska and the Operational Programme Human Capital - Priority 8.2.2, engaged in the innovative scientific research in areas considered particularly important for the development of Masovian Voivodeship for Krzysztof Miazga. Research subject was carried out with the use of CePT infrastructure (the Arcturus Laser Microdissection System, Laboratory of Molecular Neurobiology, headed by Professor B. Kamińska) financed by the European Union - the European Regional Development Fund within the Operational Programme "Innovative Economy" for 2007-2013.

\section{References}

[1] J. Hounsgaard, "Motor neurons," Comprehensive Physiology, vol. 7, no. 2, pp. 463-484, 2017.

[2] J. F. Perrier and F. Cotel, "Serotonergic modulation of spinal motor control," Current Opinion in Neurobiology, vol. 33, pp. 1-7, 2015.

[3] B. J. Schmidt and L. M. Jordan, "The role of serotonin in reflex modulation and locomotor rhythm production in the mammalian spinal cord," Brain Research Bulletin, vol. 53, no. 5, pp. 689-710, 2000.

[4] A. M. Cabaj, H. Majczyński, E. Couto et al., "Serotonin controls initiation of locomotion and afferent modulation of coordination via 5-HT7 receptors in adult rats," The Journal of Physiology, vol. 595, no. 1, pp. 301-320, 2017.

[5] F. Gackiere and L. Vinay, "Serotonergic modulation of postsynaptic inhibition and locomotor alternating pattern in the spinal cord," Frontiers in Neural Circuits, vol. 8, 2014.
[6] J. Liu and L. M. Jordan, "Stimulation of the parapyramidal region of the neonatal rat brain stem produces locomotorlike activity involving spinal 5-HT7 and 5-HT2A receptors," Journal of Neurophysiology, vol. 94, no. 2, pp. 1392-1404, 2005.

[7] J. Liu, T. Akay, P. B. Hedlund, K. G. Pearson, and L. M. Jordan, "Spinal 5-HT7 receptors are critical for alternating activity during locomotion: in vitro neonatal and in vivo adult studies using 5-HT7 receptor knockout mice," Journal of Neurophysiology, vol. 102, no. 1, pp. 337-348, 2009.

[8] M. A. Madriaga, L. C. McPhee, T. Chersa, K. J. Christie, and P. J. Whelan, "Modulation of locomotor activity by multiple 5-HT and dopaminergic receptor subtypes in the neonatal mouse spinal cord," Journal of Neurophysiology, vol. 92, no. 3, pp. 1566-1576, 2004.

[9] E. Pearlstein, F. Ben Mabrouk, J. F. Pflieger, and L. Vinay, "Serotonin refines the locomotor-related alternations in the in vitro neonatal rat spinal cord," European Journal of Neuroscience, vol. 21, no. 5, pp. 1338-1346, 2005.

[10] U. Sławińska, K. Miazga, A. M. Cabaj et al., "Grafting of fetal brainstem 5-HT neurons into the sublesional spinal cord of paraplegic rats restores coordinated hindlimb locomotion," Experimental Neurology, vol. 247, pp. 572-581, 2013.

[11] U. Sławińska, K. Miazga, and L. M. Jordan, “5-HT2 and 5-HT7 receptor agonists facilitate plantar stepping in chronic spinal rats through actions on different populations of spinal neurons," Frontiers in Neural Circuits, vol. 8, 2014.

[12] S. Hochman, S. M. Garraway, D. W. Machacek, and B. L. Shay, "5-HT receptors and the neuromodualatory control of spinal cord function," in Motor Neurobiology of the Spinal Cord, T. C. Cope, Ed., pp. 48-87, CRC Press, New York, 2001.

[13] H. Majczyński, K. Maleszak, A. Cabaj, and U. Sławińska, "Serotonin-related enhancement of recovery of hind limb motor functions in spinal rats after grafting of embryonic raphe nuclei," Journal of Neurotrauma, vol. 22, no. 5, pp. 590-604, 2005.

[14] J. M. D’Amico, E. G. Condliffe, K. J. B. Martins, D. J. Bennett, and M. A. Gorassini, "Recovery of neuronal and network excitability after spinal cord injury and implications for spasticity," Frontiers in Integrative Neuroscience, vol. 8, 2014.

[15] M. Zhang, "Normal distribution and plasticity of serotonin receptors after spinal cord injury and their impacts on motor outputs," in Recovery of Motor Function Following Spinal Cord Injury, H. Fuller and M. Gates, Eds., InTech, 2016.

[16] M. S. Hoffman and G. S. Mitchell, "Spinal 5-HT7 receptors and protein kinase A constrain intermittent hypoxiainduced phrenic long-term facilitation," Neuroscience, vol. 250, pp. 632-643, 2013.

[17] M. S. Hoffman and G. S. Mitchell, "Spinal 5-HT7 receptor activation induces long-lasting phrenic motor facilitation," The Journal of Physiology, vol. 589, no. 6, pp. 1397-1407, 2011.

[18] W. Gang, T. Hongjian, C. Jasheng et al., "The effect of the 5HT7 serotonin receptor agonist, LP44, on micturition in rats with chronic spinal cord injury," Neurourology and Urodynamics, vol. 33, no. 7, pp. 1165-1170, 2014.

[19] T. Inoue, S. Itoh, S. Wakisaka, S. Ogawa, M. Saito, and T. Morimoto, "Involvement of 5-HT7 receptors in serotonergic effects on spike afterpotentials in presumed jaw-closing motoneurons of rats," Brain Research, vol. 954, no. 2, pp. 202-211, 2002.

[20] K. Matsumoto-Miyai, M. Yoshizumi, and M. Kawatani, "Regulatory effects of 5-hydroxytryptamine receptors on voiding 
function," Advances in Therapy, vol. 32, Supplement 1, pp. 3$15,2015$.

[21] J. Ogilvie, M. Wigglesworth, L. Appleby, T. O. W. Kingston, and R. W. Clarke, "On the role of $5-\mathrm{HT} 1 \mathrm{~B} / 1 \mathrm{D}$ receptors in modulating transmission in a spinal reflex pathway in the decerebrated rabbit," British Journal of Pharmacology, vol. 128, no. 3, pp. 781-787, 1999.

[22] A. Dogrul, M. Seyrek, E. O. Akgul, T. Cayci, S. Kahraman, and H. Bolay, "Systemic paracetamol-induced analgesic and antihyperalgesic effects through activation of descending serotonergic pathways involving spinal 5-HT7 receptors," European Journal of Pharmacology, vol. 677, no. 1-3, pp. 93-101, 2012.

[23] F. Viguier, B. Michot, M. Hamon, and S. Bourgoin, "Multiple roles of serotonin in pain control mechanisms-implications of 5-HT7 and other 5-HT receptor types," European Journal of Pharmacology, vol. 716, no. 1-3, pp. 8-16, 2013.

[24] N. Cao, J. Ni, X. Wang et al., "Chronic spinal cord injury causes upregulation of serotonin (5-HT)2A and 5-HT2C receptors in lumbosacral cord motoneurons," BJU International, vol. 121, no. 1, pp. 145-154, 2018.

[25] K. Fouad, M. M. Rank, R. Vavrek, K. C. Murray, L. Sanelli, and D. J. Bennett, "Locomotion after spinal cord injury depends on constitutive activity in serotonin receptors," Journal of Neurophysiology, vol. 104, no. 6, pp. 2975-2984, 2010.

[26] P. J. Harvey, X. Li, Y. Li, and D. J. Bennett, “5-HT2 receptor activation facilitates a persistent sodium current and repetitive firing in spinal motoneurons of rats with and without chronic spinal cord injury," Journal of Neurophysiology, vol. 96, no. 3, pp. 1158-1170, 2006.

[27] D. D. Fuller, T. L. Baker-Herman, F. J. Golder, N. J. Doperalski, J. J. Watters, and G. S. Mitchell, "Cervical spinal cord injury upregulates ventral spinal 5-HT2A receptors," Journal of Neurotrauma, vol. 22, no. 2, pp. 203-213, 2005.

[28] S. Doly, J. Fischer, M. J. Brisorgueil, D. Verge, and M. Conrath, "Pre- and postsynaptic localization of the 5-HT7 receptor in rat dorsal spinal cord: immunocytochemical evidence," The Journal of Comparative Neurology, vol. 490, no. 3, pp. 256269, 2005.

[29] D. P. Fields, S. R. Springborn, and G. S. Mitchell, "Spinal 5HT7 receptors induce phrenic motor facilitation via EPACmTORC1 signaling," Journal of Neurophysiology, vol. 114, no. 3, pp. 2015-2022, 2015.

[30] P. Fenik and S. C. Veasey, "Pharmacological characterization of serotonergic receptor activity in the hypoglossal nucleus," American Journal of Respiratory and Critical Care Medicine, vol. 167, no. 4, pp. 563-569, 2003.

[31] S. Okabe, M. Mackiewicz, and L. Kubin, "Serotonin receptor mRNA expression in the hypoglossal motor nucleus," Respiration Physiology, vol. 110, no. 2-3, pp. 151-160, 1997.

[32] C. H. Gill, E. M. Soffin, J. J. Hagan, and C. H. Davies, “5-HT7 receptors modulate synchronized network activity in rat hippocampus," Neuropharmacology, vol. 42, no. 1, pp. 82-92, 2002.

[33] R. M. Brownstone, L. M. Jordan, D. J. Kriellaars, B. R. Noga, and S. J. Shefchyk, "On the regulation of repetitive firing in lumbar motoneurones during fictive locomotion in the cat," Experimental Brain Research, vol. 90, no. 3, pp. 441-455, 1992.

[34] B. J. Schmidt, "Afterhyperpolarization modulation in lumbar motoneurons during locomotor-like rhythmic activity in the neonatal rat spinal cord in vitro," Experimental Brain Research, vol. 99, no. 2, pp. 214-222, 1994.
[35] P. A. M. ban Dongen, S. Grillner, and T. Hökfelt, "5Hydroxytryptamine (serotonin) causes a reduction in the afterhyperpolarization following the action potential in lamprey motoneurons and premotor interneurons," Brain Research, vol. 366, no. 1-2, pp. 320-325, 1986.

[36] P. Wallén, J. Christenson, L. Brodin, R. Hill, A. Lansner, and S. Grillner, "Chapter 26 Mechanisms underlying the serotonergic modulation of the spinal circuitry for locomotion in lamprey," Progress in Brain Research, vol. 80, pp. 321-327, 1989.

[37] S. Doly, A. Madeira, J. Fischer et al., "The 5-HT2A receptor is widely distributed in the rat spinal cord and mainly localized at the plasma membrane of postsynaptic neurons," The Journal of Comparative Neurology, vol. 472, no. 4, pp. 496-511, 2004.

[38] V. Cornea-Hebert, M. Riad, C. Wu, S. K. Singh, and L. Descarries, "Cellular and subcellular distribution of the serotonin 5-HT2A receptor in the central nervous system of adult rat," The Journal of Comparative Neurology, vol. 409, no. 2, pp. 187-209, 1999.

[39] F. Vult von Steyern and T. Lomo, "Postnatal appearance of 5HT2A receptors on fast flexor and slow extensor rat motor neurons," Neuroscience, vol. 136, no. 1, pp. 87-93, 2005.

[40] J. K. Lee, C. S. Johnson, and J. R. Wrathall, "Up-regulation of 5-HT2 receptors is involved in the increased H-reflex amplitude after contusive spinal cord injury," Experimental Neurology, vol. 203, no. 2, pp. 502-511, 2007.

[41] J. W. Chopek, C. W. MacDonell, K. Gardiner, and P. F. Gardiner, "Daily passive cycling attenuates the hyperexcitability and restores the responsiveness of the extensor monosynaptic reflex to quipazine in the chronic spinally transected rat," Journal of Neurotrauma, vol. 31, no. 12, pp. 1083-1087, 2014.

[42] J. W. Chopek, P. C. Sheppard, K. Gardiner, and P. F. Gardiner, "Serotonin receptor and KCC2 gene expression in lumbar flexor and extensor motoneurons posttransection with and without passive cycling," Journal of Neurophysiology, vol. 113, no. 5, pp. 1369-1376, 2015.

[43] A. F. Di Narzo, A. Kozlenkov, Y. Ge et al., "Decrease of mRNA editing after spinal cord injury is caused by down-regulation of ADAR2 that is triggered by inflammatory response," Scientific Reports, vol. 5, no. 1, article 12615, 2015.

[44] I. Giroux, E. M. Kurowska, and K. K. Carroll, "Role of dietary lysine, methionine, and arginine in the regulation of hypercholesterolemia in rabbits," The Journal of Nutritional Biochemistry, vol. 10, no. 3, pp. 166-171, 1999.

[45] M. Antri, J. Y. Barthe, C. Mouffle, and D. Orsal, "Long-lasting recovery of locomotor function in chronic spinal rat following chronic combined pharmacological stimulation of serotonergic receptors with 8-OHDPAT and quipazine," Neuroscience Letters, vol. 384, no. 1-2, pp. 162-167, 2005.

[46] U. Sławińska, H. Majczyński, Y. Dai, and L. M. Jordan, “The upright posture improves plantar stepping and alters responses to serotonergic drugs in spinal rats," The Journal of Physiology, vol. 590, no. 7, pp. 1721-1736, 2012.

[47] E. S. Landry, N. P. Lapointe, C. Rouillard, D. Levesque, P. B. Hedlund, and P. A. Guertin, "Contribution of spinal 5-HT1A and 5-HT7 receptors to locomotor-like movement induced by $8-\mathrm{OH}-\mathrm{DPAT}$ in spinal cord-transected mice," The European Journal of Neuroscience, vol. 24, no. 2, pp. 535-546, 2006.

[48] R. Bos, K. Sadlaoud, P. Boulenguez et al., "Activation of 5$\mathrm{HT} 2 \mathrm{~A}$ receptors upregulates the function of the neuronal $\mathrm{K}-\mathrm{Cl}$ cotransporter KCC2," Proceedings of the National 
Academy of Sciences of the United States of America, vol. 110, no. 1, pp. 348-353, 2013.

[49] M. J. Dunbar, M. A. Tran, and P. J. Whelan, "Endogenous extracellular serotonin modulates the spinal locomotor network of the neonatal mouse," The Journal of Physiology, vol. 588, no. 1, pp. 139-156, 2010.

[50] M. Antri, C. Mouffle, D. Orsal, and J. Y. Barthe, "5-HT1A receptors are involved in short- and long-term processes responsible for 5-HT-induced locomotor function recovery in chronic spinal rat," The European Journal of Neuroscience, vol. 18, no. 7, pp. 1963-1972, 2003.

[51] U. Sławińska, H. Majczyński, and R. Djavadian, "Recovery of hindlimb motor functions after spinal cord transection is enhanced by grafts of the embryonic raphe nuclei," Experimental Brain Research, vol. 132, no. 1, pp. 27-38, 2000.

[52] K. C. Murray, A. Nakae, M. J. Stephens et al., "Recovery of motoneuron and locomotor function after spinal cord injury depends on constitutive activity in 5-HT2C receptors," Nature Medicine, vol. 16, no. 6, pp. 694-700, 2010.

[53] U. Sławińska, L. M. Jordan, B. Burger, H. Fabczak, and H. Majczyński, "Locomotion of intact adult rats is controlled by 5-HT2A and 5-HT7 but not 5-HT2C receptors; 2012," in Society of Neuroscience, Neuroscience Meeting Planner, New Orleans, LA, USA, 2012, Program No. 85.09.

[54] K. L. Wohlpart and P. B. Molinoff, "Regulation of levels of 5HT2A receptor mRNA," Annals of the New York Academy of Sciences, vol. 861, no. 1 ADVANCES IN S, pp. 128-135, 1998.

[55] D. Van Oekelen, W. H. M. L. Luyten, and J. E. Leysen, "5$\mathrm{HT} 2 \mathrm{~A}$ and 5-HT2C receptors and their atypical regulation properties," Life Sciences, vol. 72, no. 22, pp. 2429-2449, 2003.

[56] K. Miazga, E. Joachimiak, H. Fabczak, and U. Sławińska, "Grafted serotonergic neurons can reverse changes in gene expression in motoneurons produced by spinal cord injury in rats.; 2015. Programm: P9.6," in 12th International Congress of the Polish Neuroscience Society, Gdańsk, Poland, September 2015.

[57] U. Sławińska, K. Miazga, and L. M. Jordan, "The role of serotonin in the control of locomotor movements and strategies for restoring locomotion after spinal cord injury," Acta Neurobiologiae Experimentalis, vol. 74, no. 2, pp. 172-187, 2014.

[58] A. Lev-Tov, A. Etlin, and D. Blivis, "Sensory-induced activation of pattern generators in the absence of supraspinal control," Annals of the New York Academy of Sciences, vol. 1198, no. 1 , pp. 54-62, 2010.

[59] D. Feraboli-Lohnherr, D. Orsal, A. Yakovleff, M. Gimenez y Ribotta, and A. Privat, "Recovery of locomotor activity in the adult chronic spinal rat after sublesional transplantation of embryonic nervous cells: specific role of serotonergic neurons," Experimental Brain Research, vol. 113, no. 3, pp. 443454, 1997.

[60] M. G. y Ribotta, J. Provencher, D. Feraboli-Lohnherr, S. Rossignol, A. Privat, and D. Orsal, "Activation of locomotion in adult chronic spinal rats is achieved by transplantation of embryonic raphe cells reinnervating a precise lumbar level," The Journal of Neuroscience, vol. 20, no. 13, pp. 5144-5152, 2000.

[61] D. M. Basso, M. S. Beattie, and J. C. Bresnahan, "Graded histological and locomotor outcomes after spinal cord contusion using the NYU weight-drop device versus transection," Experimental Neurology, vol. 139, no. 2, pp. 244-256, 1996.
[62] R. C. Ferry, C. D. Unsworth, R. P. Artymyshyn, and P. B. Molinoff, "Regulation of mRNA encoding 5-HT2A receptors in $\mathrm{P} 11$ cells through a post-transcriptional mechanism requiring activation of protein kinase C," The Journal of Biological Chemistry, vol. 269, no. 50, pp. 31850-31857, 1994.

[63] X. Y. Kong, J. Wienecke, M. Chen, H. Hultborn, and M. Zhang, "The time course of serotonin 2a receptor expression after spinal transection of rats: an immunohistochemical study," Neuroscience, vol. 177, pp. 114-126, 2011.

[64] X.-Y. Kong, J. Wienecke, H. Hultborn, and M. Zhang, "Robust upregulation of serotonin $2 \mathrm{~A}$ receptors after chronic spinal transection of rats: an immunohistochemical study," Brain Research, vol. 1320, pp. 60-68, 2010.

[65] Y. Zhang, R. X. Zhang, M. Zhang et al., "Electroacupuncture inhibition of hyperalgesia in an inflammatory pain rat model: involvement of distinct spinal serotonin and norepinephrine receptor subtypes," British Journal of Anaesthesia, vol. 109, no. 2, pp. 245-252, 2012.

[66] Y. Ryu, T. Ogata, M. Nagao et al., "The swimming test is effective for evaluating spasticity after contusive spinal cord injury," PLoS One, vol. 12, no. 2, article e0171937, 2017.

[67] Y. Ryu, T. Ogata, M. Nagao, Y. Sawada, R. Nishimura, and N. Fujita, "Effects of treadmill training combined with serotonergic interventions on spasticity after contusive spinal cord injury," Journal of Neurotrauma, vol. 35, no. 12, pp. 13581366, 2018.

[68] R. V. Ung, E. S. Landry, P. Rouleau, N. P. Lapointe, C. Rouillard, and P. A. Guertin, "Role of spinal 5-HT2 receptor subtypes in quipazine-induced hindlimb movements after a low-thoracic spinal cord transection," European Journal of Neuroscience, vol. 28, no. 11, pp. 2231-2242, 2008.

[69] T. Maier, M. Guell, and L. Serrano, "Correlation of mRNA and protein in complex biological samples," FEBS Letters, vol. 583, no. 24, pp. 3966-3973, 2009.

[70] C. B. Mantilla, J. P. Bailey, W. Z. Zhan, and G. C. Sieck, "Phrenic motoneuron expression of serotonergic and glutamatergic receptors following upper cervical spinal cord injury," Experimental Neurology, vol. 234, no. 1, pp. 191-199, 2012.

[71] M. Zaniewska, N. Alenina, K. Wydra et al., "Discovering the mechanisms underlying serotonin (5-HT)2A and 5-HT2C receptor regulation following nicotine withdrawal in rats," Journal of Neurochemistry, vol. 134, no. 4, pp. 704-716, 2015.

[72] J. Celichowski, W. Mrówczyński, P. Krutki, T. Górska, H. Majczyński, and U. Sławińska, "Changes in contractile properties of motor units of the rat medial gastrocnemius muscle after spinal cord transection," Experimental Physiology, vol. 91, no. 5, pp. 887-895, 2006.

[73] A. Ishihara, F. Nagatomo, H. Fujino, H. Kondo, and Y. Ohira, "Decreased succinate dehydrogenase activity of gamma and alpha motoneurons in mouse spinal cords following 13 weeks of exposure to microgravity," Neurochemical Research, vol. 38, no. 10, pp. 2160-2167, 2013.

[74] A. Ishihara, R. R. Roy, and V. R. Edgerton, "Succinate dehydrogenase activity and soma size of motoneurons innervating different portions of the rat tibialis anterior," Neuroscience, vol. 68 , no. 3, pp. 813-822, 1995.

[75] S. Navarrett, L. Collier, C. Cardozo, and S. Dracheva, "Alterations of serotonin $2 \mathrm{C}$ and $2 \mathrm{~A}$ receptors in response to T10 spinal cord transection in rats," Neuroscience Letters, vol. 506, no. 1, pp. 74-78, 2012. 
[76] N. Herr, C. Bode, and D. Duerschmied, "The effects of serotonin in immune cells," Frontiers in Cardiovascular Medicine, vol. 4, p. 48, 2017.

[77] D. P. Fields and G. S. Mitchell, "Divergent cAMP signaling differentially regulates serotonin-induced spinal motor plasticity," Neuropharmacology, vol. 113, no. Part A, pp. 82-88, 2017.

[78] D. D. Fuller and G. S. Mitchell, "Respiratory neuroplasticity overview, significance and future directions," Experimental Neurology, vol. 287, Part 2, pp. 144-152, 2017.

[79] L. Zhang, "Effects of 5-hydroxytryptamine on cat spinal motoneurons," Canadian Journal of Physiology and Pharmacology, vol. 69, no. 2, pp. 154-163, 1991.

[80] S. R. White and S. J. Fung, "Serotonin depolarizes cat spinal motoneurons in situ and decreases motoneuron afterhyperpolarizing potentials," Brain Research, vol. 502, no. 2, pp. 205213, 1989. 


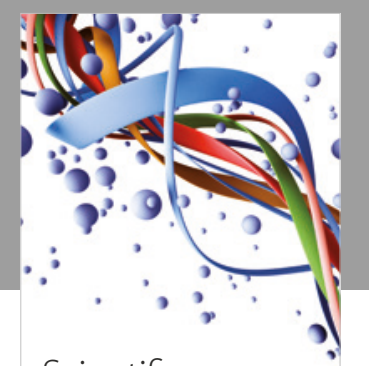

Scientifica
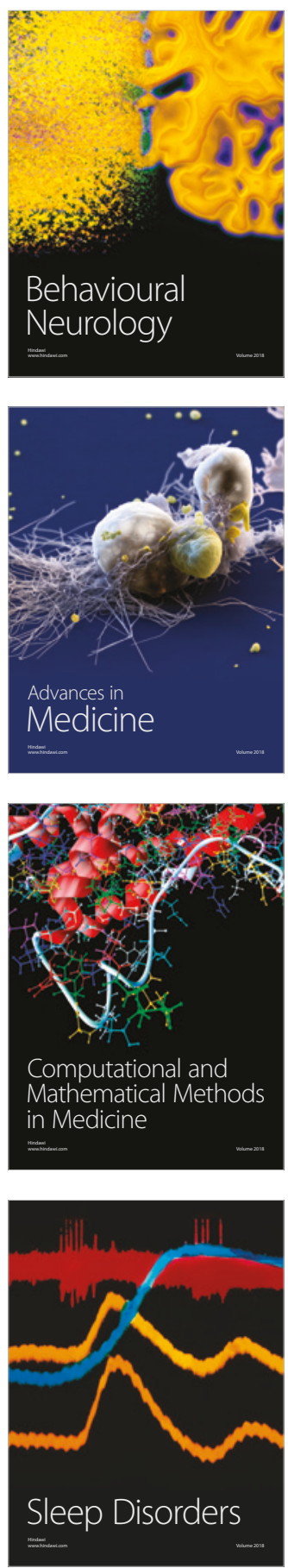

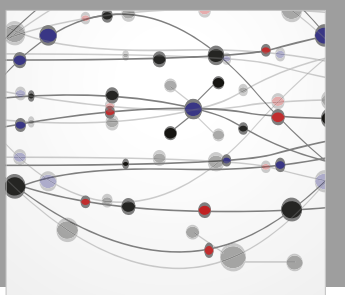

The Scientific World Journal

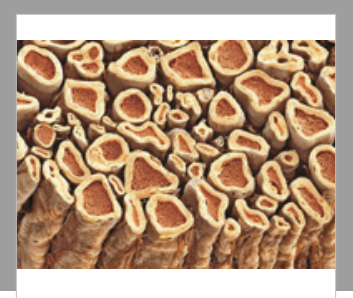

Case Reports in

Neurological Medicine

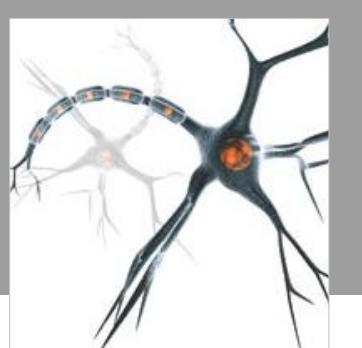

Neural Plasticity

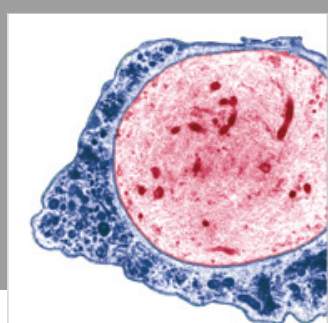

Multiple Sclerosis

International

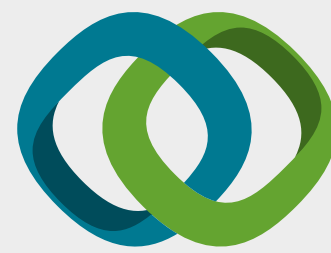

Hindawi

Submit your manuscripts at

www.hindawi.com
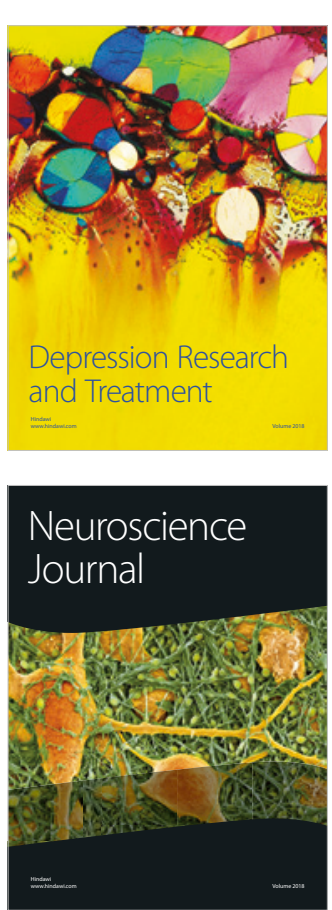

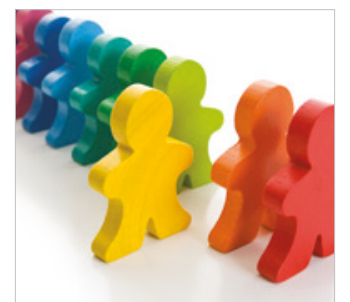

Autism

Research and Treatment
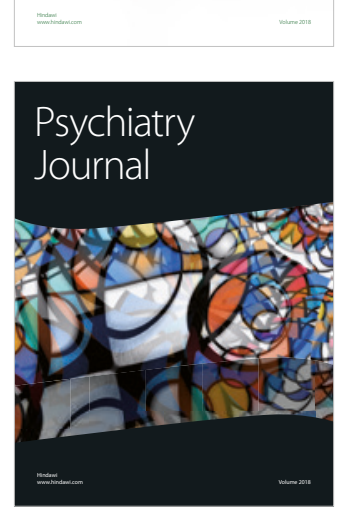
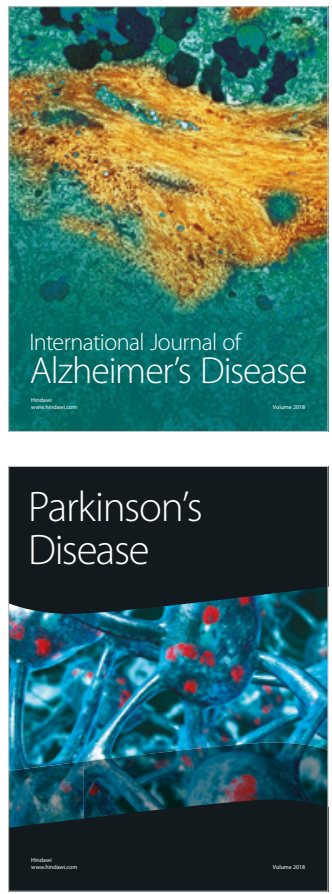
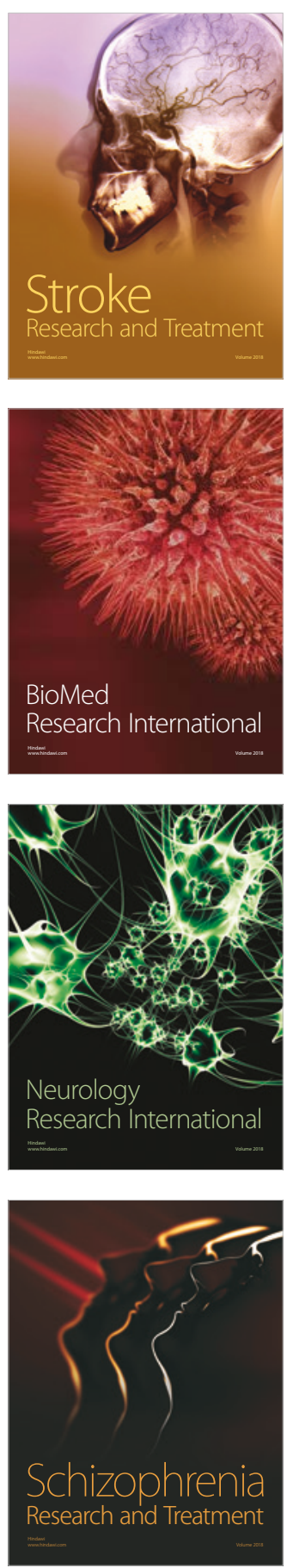